OPEN ACCESS

Edited by:

Ping Wang,

Michigan State University, United States

Reviewed by:

Alok Raghav,

Ganesh Shankar Vidyarthi Memorial Medical College, India

Anwar Abdullah Borai,

King Saud bin Abdulaziz University for

Health Sciences, Saudi Arabia

${ }^{*}$ Correspondence:

Qi Liu

staff1177@yxph.com

Lei Wang

Wlei@nju.edu.cn

${ }^{\dagger}$ These authors have contributed equally to this work

Specialty section: This article was submitted to Clinical Diabetes,

a section of the journa

Frontiers in Endocrinology

Received: 10 August 2021 Accepted: 01 October 2021 Published: 26 October 2021

Citation:

Sun Y, Tao Q, Wu X, Zhang L, Liu Q and Wang $L$ (2021) The Utility of

Exosomes in Diagnosis and Therapy of Diabetes Mellitus and Associated Complications.

Front. Endocrinol. 12:756581. doi: 10.3389/fendo.2021.756581

\section{The Utility of Exosomes in Diagnosis and Therapy of Diabetes Mellitus and Associated Complications}

\author{
Yaoxiang Sun ${ }^{1 \dagger}$, Qing $\mathrm{Tao}^{2 \dagger}$, Xueqin Wu ${ }^{1}$, Ling Zhang ${ }^{1}$, Qi Liu ${ }^{1 *}$ and Lei Wang ${ }^{2 *}$ \\ 1 Department of Clinical Laboratory, Yixing People's Hospital, Yixing, China, ${ }^{2}$ Center for Translational Medicine and Jiangsu \\ Key Laboratory of Molecular Medicine, Medical School of Nanjing University, Nanjing, China
}

Diabetes mellitus and the associated complications are metabolic diseases with high morbidity that result in poor quality of health and life. The lack of diagnostic methods for early detection results in patients losing the best treatment opportunity. Oral hypoglycemics and exogenous insulin replenishment are currently the most common therapeutic strategies, which only yield temporary glycemic control rather than curing the disease and its complications. Exosomes are nanoparticles containing bioactive molecules reflecting individual physiological status, regulating metabolism, and repairing damaged tissues. They function as biomarkers of diabetes mellitus and diabetic complications. Considering that exosomes are bioactive molecules, can be obtained from body fluid, and have cell-type specificity, in this review, we highlight the multifold effects of exosomes in the pathology and therapy of diabetes mellitus and diabetic complications.

Keywords: exosomes, biomarkers, diabetes mellitus, therapy, diagnosis, mesenchymal stem cells

\section{INTRODUCTION}

Exosomes are membranous extracellular vesicles (EVs) first discovered in 1983; for several years, they have been described as organelles removing metabolic waste out of cells (1). Exosomes can be isolated from body fluids such as blood, urine, cerebrospinal fluid (CSF), amniotic fluid, and saliva, and from different cell types in vitro such as stem cells, dendritic cells, mast cells, and T cells $(2,3)$. Recent studies on exosomes extracted from body fluid in vivo and culture media in vitro have shown that they can provide information about the tissues or cells of their origin and that they act as messengers in cell-cell communication and deliver bioactive molecules such as proteins and nucleic acids, apart from removing cellular waste $(4,5)$. These studies suggest that exosomes play important roles in non-invasive diagnosis (6) and impaired tissue repair (7).

Diabetes mellitus (DM) is a metabolic disease with high morbidity. It significantly deteriorates the quality of health and life. Early diagnostic methods for diabetes remain lacking, resulting in patients losing the optimal treatment opportunity, which increases the risk of diabetic complications (8). Current therapeutic options include oral hypoglycemic drugs or insulin injections, which provide temporary blood glucose level control; however, these therapies cannot prevent diabetic complications and are associated with adverse effects such as hypoglycemia (9). In this review, we 
summarize the recent evidence on exosomes as biomarkers and therapeutic factors for DM and its complications in clinical practice.

\section{INTRODUCTION TO AND CHARACTERIZATION OF EXOSOMES}

Exosomes are microvesicles released by cells into the extracellular space, sized around $30-200 \mathrm{~nm}$. Generally, the size of exosomes is at the nanometer level, and the unit for detecting the concentration of exosomes is units/microliter. They can be recognized as a heterogeneous population of membranebound structures ("cup-like" or "dish-like") under a transmission electron microscope (10). Chemical or physical stimulations such as cytokines, unesterified cholesterol, thrombin, tobacco smoke extract $(11,12)$, hypoxia, and shear stress activate or induce cell apoptosis, which results in the budding of the endosomal membrane, forming multivesicular bodies (MVBs). MVBs and the plasma membrane fuse and finally lead to the release of exosomes $(13,14)$. Exosomes can be released by most cell types such as cancer cells, stem cells, skeletal muscles cells, mast cells, dendritic cells, and lymphocytes. The most common components in the evaluation of exosomes are the following categories: functional miRNA, a small amount of mRNA, long non-coding RNA (lncRNA), and specific proteins (such as cytokines and growth factors) and other biologically active substances, which are protected from hydrolase activity by the lipid from the original cells and the membrane structures, allowing exosomes to act as cell communication messengers and influence biological function in target cells by fusion, endocytosis, and receptor-ligand interaction $(6,14-17)$. These are not total components and just one of the components. Exosomes can be extracted from the serum, urine, cerebral spinal fluid, saliva, and bronchiolar lavage fluid $(2,18)$. The level of exosomes is generally through the detection of their morphology, namely, particle size and concentration. Three main methods are used: morphology (electron microscopy), particle size (diameter particle analysis), and marker protein (WB) (19). Exosome density ranges from 1.13 to $1.21 \mathrm{~g} / \mathrm{ml}$, allowing the use of the sucrose-deuteroxide density gradient separation method to isolate them (20). In addition, exosomes can also be extracted using ultra-centrifugation or the ExoQuick exosome precipitation solution $(8,21)$. CD9, CD63, and CD81 are the accepted surface markers on exosomes for identification using Western blotting (20), quantitative RT-PCR, nucleic acid sequencing, enzyme-linked immunosorbent assay (ELISA), and flow cytometry (FCM).

As exosomes are stable and cell-type specific and can be isolated non-invasively/minimally invasively, they have been extensively studied, particularly in tumorigenesis (22-25) and diagnosis of DM and diabetic complications. Physiologically, exosomes can repair tissue damage, particularly exosomes derived from stem cells $(7,20,26,27)$. Pancreatic, vascular, kidney, nervous, and skin injuries are commonly associated with DM onset and diabetic complications (28-31). Exosomes can physiologically contribute to the repair of such injuries.

\section{EXOSOMES AS THE POTENTIAL BIOMARKERS OF DIABETES MELLITUS AND DIABETIC COMPLICATIONS}

\subsection{Introduction to Diabetes Mellitus}

DM mainly includes type $1 \mathrm{DM}$ (T1DM) and type $2 \mathrm{DM}$ (T2DM). Under physiological conditions, fasting blood glucose levels should be 3.9-6.1 mM given normal secretion of insulin and tissue insulin sensitivity. Various factors such as genetic inheritance, viral infection, unhealthy lifestyle, and other physical or chemical damages lead to $\beta$-cell destruction, impaired insulin secretion, and loss of peripheral tissue insulin sensitivity, finally resulting in a high blood glucose level (28). T1DM accounts for $10 \%$ of DM cases and is characterized by absolute insufficiency of insulin, often presenting with symptoms such as thirst, weight loss, and polyuria. T2DM, characterized by insulin resistance in target tissue, relatively insufficient insulin secretion, and subsequent $\beta$-cell dysfunction, is often nonsymptomatic; and patients with T2DM seek medical care only for complications such as vision loss, heart attack, or limb gangrenes $(28,32)$. The frequently used diagnostic methods for diabetes include fasted or random blood glucose level measurement for preliminary screening, homeostatic model assessment-insulin resistance (HOMA-IR), oral glucose tolerance tests (OGTTs), intraperitoneal glucose tolerance test for detecting the sensitivity of peripheral tissues to glucose and insulin, serum insulin level, homeostatic model assessment $\beta$ (HOMA- $\beta$ ) and insulin release tests for determining the function of $\beta$ cells, and glycated hemoglobin (HbAlc) for indicating the blood glucose level for the previous 8-12 weeks $(28,33)$.

\subsection{Introduction to Diabetic Complications}

A chronic high blood glucose level disrupts homeostasis, causes oxidant stress, and induces microvessel, nervous, and immune system damage, finally exacerbating the development of diabetic complications (34). Cardiomyopathy is induced by an increased fatty acid metabolism, reduced myofilament $\mathrm{Ca}^{+}$sensitivity, mitochondrial dysfunction, oxidative stress, apoptosis, and fibrosis of diabetic cardiomyocytes (35-37). Pathologic glucose metabolism also damages the blood vessels structurally and functionally, resulting in apoptosis and fibrosis in microvessels, inducing diabetic nephropathy, glomerular atrophy, renal fibrosis, renal dysfunction, and renal failure $(29,38)$. In the retina, microvessel apoptosis and paraplasm may also result in microaneurysms and hemorrhage, which are diagnosed as diabetic retinopathy and finally cause vision loss (30). Poor glucose control induces peripheral neuropathy and peripheral vascular disease combined with structural deformities, and environmental factors and compromised immunity lead to the development of diabetic foot (31).

Furthermore, heart attack, vision loss, renal dysfunction, and refractory wound healing are often apparent before DM diagnosis, and these symptoms indicate significant organ injury. Therefore, early detection of DM and diabetic complications is crucial; however, no definitive methods of early diagnosis exist (28). 


\subsection{Potential of Exosomes in Non-Invasive/ Minimally Invasive Diagnosis}

Exosomes are a medium of cell-cell communication and carry several bioactive substances from the original cells including proteins, RNA, DNA, and lipid derivatives $(6,39,40)$; they have been studied in both physiological and pathological circumstances such as exercise, cancer, neurodegenerative disorders, and metabolic diseases (41-44). DM and diabetic complications are systemic diseases and affect several organs. The following factors allow the potential use of exosomes in the diagnosis of systemic diseases: 1) exosomes can be derived from the serum, urine, and CSF and contain several bioactive materials like proteins, nucleic acids, and lipids, which can provide information about almost the entire body (14, 45-47). Urine and serum are the common specimen sources of exosomes in DM and associated complication diagnosis; the collection of urine is quite convenient, which can be operated by patients themselves non-invasively; and the collection of blood or CSF is minimally invasive, which can cause no obvious discomfort; 2) exosomes are relatively stable and allow prolonged storage given their membranous structures, which provide structural integrity to bioactive molecules; this feature makes sure of the authenticity and accuracy of results in subsequent tests in that the bilayer structure can avoid the degradation of different kinds of enzyme such as proteolytic enzyme or RNase (48); 3) analysis techniques such as liquid chromatography-mass spectrometry (LC/MS), protein or gene chip analysis, liquid biopsy, FCM, and magnetic bead-based analysis have sufficiently matured to allow using exosomes or tests. The LC/MS can be used to analyze the type and quantity of proteins or metabolites, and genetic sequencing is an important tool of nucleic acid analysis, are which contained in exosomes derived from body fluid of DM or related patients. Besides, Western blotting and qRT-PCR can be used to verify the correlated data in different groups (48-51); 4) several methods for isolation of exosomes exist with acceptable costs (Table 1). Ultra-centrifugation is the gold standard method for exosomes isolation, which can promise the highest purity; however, the facility request and operating steps are quite tedious, and the output is quite low; these characteristics result in the low inspection efficiency, which is not clinically applicable (44-46). Sucrose/heavy water density gradient is the improved method of ultra-centrifugation, which increases the output of exosomes, but the steps are still very cumbersome (51). Exosome isolation kit is the most common and convenient method, which has high yield, but the high yield is built on the sacrificing purity (44). In addition, several other methods develop gradually such as magnetic bean sorting, filter device, and flow sorting; in this manners, exosomes can be captured accurately depending on the expensive equipment and consumables and will be the mainstream approach in the future $(48,52-54)$.

Herein, we present a review of the recent advances in the use of exosomes as potential early diagnostic biomarkers (Table 2) of DM and diabetic complications in different ways, particularly of the recent ones, and the detailed information will be described, as follows.

\subsubsection{Diabetes Mellitus and Diabetic Complications Result in a Change in Exosome Count}

The count of exosomes derived from circulating cells differs significantly between those with diabetes and those without, as chronic high glucose levels result in inflammatory cell activation and endothelial cell apoptosis (74). Meta-analyses have revealed a notable increase in circulating exosomes released by platelets, monocytes, and endothelial cells in diabetes; however, exosomes from leucocytes do not differ between patients with diabetes and controls $(57,58)$. A high glucose concentration can induce a threefold increase in exosomes from endothelial cells (59). A study reported that the count of total exosomes isolated from gingival crevicular fluid of pregnant women who developed gestational DM (GDM) later in pregnancy was significantly higher than in normoglycemic pregnant women (75). In diabetic nephropathy, urinary podocyte exosome counts are higher in patients with T2DM, preceding changes in other biomarkers such as urine albumin or nephrin (an early biomarker of glomerular injury) (76). The exosome counts can be assessed using NanoSight or FCM. Both NanoSight and FCM are experimental methods used to evaluate exosomes. NanoSight technology can detect the size distribution and concentration of purified exosomes through nanoparticle tracking analysis (NTA) (77-79). FCM can be used to observe the number of exosomes and their surface markers (80). It also can be used to identify various exosomal subpopulations (81). The detection of exosomes in the disease through the above techniques may be the most easily accessible method for early screening of DM or diabetes complications.

\subsubsection{Differences in Exosome Contents Between Individuals With or Without Diabetes}

Although the contents of exosomes between patients with DM have also been reported to vary, the difference is significant in case of diabetic complications. Exosomal proteins derived from body

TABLE 1 | Methods of exosome isolation and evaluation.

\begin{tabular}{|c|c|c|c|c|}
\hline Method & Principle & Advantage & Disadvantage & Reference \\
\hline Sucrose/heavy water density gradient & Special density & Effective, low cost & Laborious, low yield, & $(20,52)$ \\
\hline $\begin{array}{l}\text { Magnetic beans } \\
\text { sorting }\end{array}$ & Immunoreaction & High precision, direct analysis target molecular & Laborious, high cost & (49) \\
\hline Filter device & Special diameter & High precision, direct analysis of target molecules & High cost & (53) \\
\hline Flow sorting & Immunoreaction & High precision, direct analysis of target molecule & Laborious, high cost & $(54,55)$ \\
\hline
\end{tabular}


TABLE 2 | Exosomes derived from body fluid can act as novel biomarkers for early diagnosis of DM and diabetic complications.

\begin{tabular}{|c|c|c|c|c|c|}
\hline Disease & $\begin{array}{l}\text { Target } \\
\text { content in } \\
\text { exosome }\end{array}$ & Sample & Method & Scientific mechanism & Reference \\
\hline T2DM & $\begin{array}{l}\text { Counts of cell } \\
\text { derived } \\
\text { exosomes } \uparrow\end{array}$ & Serum & $\begin{array}{l}\text { Flow } \\
\text { cytometry } \\
\text { meta- } \\
\text { analysis }\end{array}$ & $\begin{array}{l}\text { 1. Total annexin V-positive blood cell microparticles-procoagulant activity could be involved } \\
\text { in vascular complications } 2 \text {. Endothelial microparticles stimulated by elevated glucose change } \\
\text { their molecular composition and increase their biological activity, which may lead to } \\
\text { progressive endothelial damage and subsequent cardiovascular complications in diabetes }\end{array}$ & $(57-59)$ \\
\hline \multirow[t]{9}{*}{$\begin{array}{l}\text { Diabetes } \\
\text { nephropathy }\end{array}$} & $\begin{array}{l}\text { Counts of cell } \\
\text { derived } \\
\text { exosomes } \uparrow\end{array}$ & Urinary & $\begin{array}{l}\text { Flow } \\
\text { cytometry }\end{array}$ & MiR-26a-5p from adipose-derived mesenchymal stem cell-derived EVs protect against DN & \\
\hline & $\begin{array}{l}\text { Dipeptidyl } \\
\text { peptidase-IV } \uparrow\end{array}$ & Urinary & ELISA & $\begin{array}{l}\text { The urinary level of microvesicle-bound microvesicle-dipeptidyl peptidase-IV is associated with } \\
\text { the severity of diabetic kidney disease }\end{array}$ & (38) \\
\hline & $\begin{array}{l}\text { Wilms tumor-1 } \\
\uparrow\end{array}$ & Urinary & $\begin{array}{l}\text { Western } \\
\text { blotting }\end{array}$ & $\begin{array}{l}\text { Among podocyte-derived signal transduction factors in urinary exosomes, WT1 mRNA levels } \\
\text { reflected damage of diabetic glomeruli in the patients }\end{array}$ & $(60)$ \\
\hline & $\begin{array}{l}\text { AMBP, MLL3 } \\
\uparrow \text { VDAC1 } \downarrow\end{array}$ & Urinary & LC-MS/MS & $\begin{array}{l}\text { Comparing DN urine exosomes and healthy controls, it was discovered in a panel of three } \\
\text { proteins (AMBP, MLL3, and VDAC1) that they were differentially found in urinary exosomes } \\
\text { from DN patients }\end{array}$ & $(61)$ \\
\hline & $\begin{array}{l}\text { MiR-130, miR- } \\
145, \operatorname{miR}-155 \\
\operatorname{miR}-424 \uparrow\end{array}$ & Urinary & $\begin{array}{l}\text { TaqMan } \\
\text { qPCR }\end{array}$ & $\begin{array}{l}\text { High glucose will stimulate mesangial cells and increase the content of miR-145 in mesangial } \\
\text { cells and their derived exosomes }\end{array}$ & $(62)$ \\
\hline & $\begin{array}{l}\text { Mitochondrial } \\
\text { DNA } \downarrow\end{array}$ & Urinary & $\begin{array}{l}\text { Intrarenal } \\
\text { Gene } \\
\text { Expression } \\
\text { Analysis }\end{array}$ & $\begin{array}{l}\text { Urine exosomes from patients with diabetes and CKD had less mitochondrial DNA, and } \\
\text { kidney tissues from patients with diabetic kidney disease had lower gene expression of } \\
\text { PGC1 } \alpha\end{array}$ & $(63)$ \\
\hline & Elf3 $\uparrow$ & Urinary & $\begin{array}{l}\text { Western } \\
\text { blotting }\end{array}$ & $\begin{array}{l}\text { AGE treatment induced the secretion of Elf3-containing exosomes from cultured podocytes, } \\
\text { which was dependent on the activation of the TGF- } \beta \text {-Smad3 signaling pathway }\end{array}$ & $(64)$ \\
\hline & $\operatorname{MiR}-16 \downarrow$ & Urinary & RT-qPCR & $\begin{array}{l}\text { MiR-16 identified as the most stable endogenous reference gene in data set, making it a } \\
\text { suitable endogenous reference gene for miRNA studies of urinary exosomes derived from } \\
\text { CKD patients }\end{array}$ & (65) \\
\hline & $\begin{array}{l}\text { Gelatinase } \\
\downarrow \text { ceruloplasmin } \\
\uparrow\end{array}$ & Urinary & ELISA & $\begin{array}{l}\text { Gelatinase (decreased activity) and ceruloplasmin (increased levels), in the urinary exosomes } \\
\text { of diabetic kidney patients were in agreement with the alterations of these two proteins in the } \\
\text { kidney tissue }\end{array}$ & $(66)$ \\
\hline \multirow[t]{5}{*}{$\begin{array}{l}\text { Diabetic } \\
\text { cardiomyocytes }\end{array}$} & $\begin{array}{l}\text { Counts of } \\
\text { exosomes } \uparrow\end{array}$ & Blood & $\begin{array}{l}\text { Flow } \\
\text { cytometry }\end{array}$ & $\begin{array}{l}\text { Exosomes from diabetic rats no longer activated the ERK1/2 and HSP27 cardioprotective } \\
\text { pathway and were no longer protective in a primary rat cardiomyocyte model of hypoxia and } \\
\text { reoxygenation injury. Exosomes from diabetic plasma have lost the ability to protect } \\
\text { cardiomyocytes, but protection can be restored with exosomes from non-diabetic plasma }\end{array}$ & \\
\hline & Hsp20 $\downarrow$ & Serum & LC-MS/MS & $\begin{array}{l}\text { Elevation of Hsp2O in cardiomyocytes can offer protection in diabetic hearts through the } \\
\text { release of instrumental exosomes }\end{array}$ & (67) \\
\hline & $\mathrm{MiR}-320 \uparrow$ & Serum & $\begin{array}{l}\text { TaqMan } \\
\text { qPCR }\end{array}$ & $\begin{array}{l}\text { Cardiomyocytes exert an anti-angiogenic function in type } 2 \text { diabetic rats through exosomal } \\
\text { transfer of miR-320 into endothelial cells }\end{array}$ & (68) \\
\hline & MiR-126 $\downarrow$ & Serum & $\begin{array}{l}\text { TaqMan } \\
\text { qPCR }\end{array}$ & $\begin{array}{l}\text { MiR-126 targets insulin receptor substrate (IRS)-1 expression via PI3K/Akt signaling pathways } \\
\text { suggests that it is involved in IR modulation }\end{array}$ & (69) \\
\hline & $\mathrm{MiR}-7 \uparrow$ & Serum & RT-qPCR & MiR-7 was demonstrated to be involved in $\beta$-cell dysfunction and insulin secretion & $(70)$ \\
\hline $\begin{array}{l}\text { Diabetic Charcot } \\
\text { neuroarthropathy } \\
\text { (CN) }\end{array}$ & $\begin{array}{l}\text { Counts of } \\
\text { exosomes } \uparrow\end{array}$ & Plasma & $\begin{array}{l}\text { Flow } \\
\text { cytometry }\end{array}$ & $\begin{array}{l}\text { The concentration of EVs is related to elevation of markers of inflammation (CRP and foot } \\
\text { temperature difference) in acute diabetic } \mathrm{CN}\end{array}$ & (71) \\
\hline $\begin{array}{l}\text { Gestational } \\
\text { diabetes }\end{array}$ & $\begin{array}{l}\text { Counts of } \\
\text { endothelial cell } \\
\text { exosomes } \uparrow\end{array}$ & $\begin{array}{l}\text { Serum, } \\
\text { plasma }\end{array}$ & $\begin{array}{l}\text { Western } \\
\text { blotting, } \\
\text { RT-qPCR }\end{array}$ & $\begin{array}{l}\text { Exosomal Ang } 2 \text { secretion is regulated by the PI3K/Akt/eNOS and syndecan-4/syntenin } \\
\text { pathways }\end{array}$ & $(72,73)$ \\
\hline
\end{tabular}

DM, diabetes mellitus; T2DM, type 2 diabetes mellitus; EV, extracellular vesicle; DN, diabetic nephropathy; LC-MS/MS, liquid chromatography-tandem MS; CKD, chronic kidney disease; AGE, advanced glycation end-product; CRP, C-reactive protein.

fluids of patients with DM differ; for example, dipeptidyl peptidase-IV (DPP IV) that activates glucagon-like peptide-1 (GLP-1) is associated with DM. In addition, the microvesiclebound type is the major form of DPP IV in urine, which is significantly higher among those with T2DM than among controls (38). The levels of Wilms tumor protein 1 in urinary exosomes are significantly higher in patients with diabetes with proteinuria, which implies that exosomes can be early biomarkers of podocyte injury (60). The changes in miRNA levels can be detected also in exosomes in diabetes patients with and without diabetic complications. For example, Lange et al. found that the level of miR-16 was lower in the urine of patients with diabetic nephropathy than of healthy controls (65). Individuals with T2DM and T2DM-associated microvascular complications have a significantly higher level of miR-7 in serum-derived exosomes than do individuals without. Accordingly, the changes in these biomarkers in exosomes precede organ-level changes and provide more specificity than whole urine or blood, which further consolidates the potential role of exosomes in early diagnosis of DM and diabetic complications (Figure 1). 

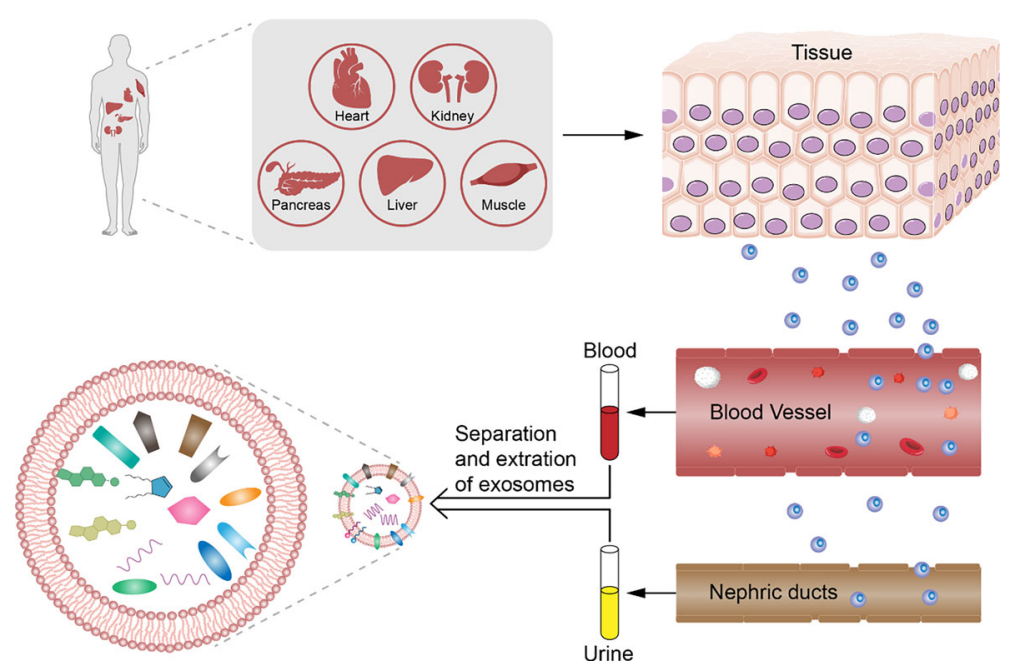

FIGURE 1 | Analysis of exosomes from patients with diabetes mellitus. Diabetes mellitus and diabetic complications have pathological change before organic damage in exosomes derived from body fluids. We can collect the serum, plasma, and urine non-invasively and analyze the counts and contents such as DNA, RNA, and protein depending on the differences between healthy control by choosing the significant biomarker for early diagnosis of diabetes mellitus and diabetic complications.

\section{EXOSOMES AS A POTENTIAL THERAPEUTIC TARGET FOR DIABETES MELLITUS AND DIABETIC COMPLICATIONS}

\subsection{The Disadvantages of Traditional Treatment for Diabetes Mellitus and Diabetic Complications}

Herein, we focus on common therapeutic strategies for the treatment of DM and its complications (Table 3) apart from lifestyle optimizations such as diet control and physical exercise. Insulin injection is the most important therapeutic approach in the treatment of DM and diabetic complications. However, if its dose is not precisely controlled, it can induce life-threatening hypoglycemia $(32,97)$. Oral hypoglycemic drugs also play key roles in blood glucose level management. Hypoglycemics have been divided into several types depending on their mechanism of blood glucose regulation. For instance, metformin can increase peripheral tissue insulin sensitivity, whereas sulfonylureas can stimulate insulin secretion. Of relevance, these hypoglycemic drugs have adverse effects depending on the mechanism of blood glucose regulation, such as gastrointestinal tract response, hypoglycemia, hypoleucocytosis, hemolytic anemia, increased risk of major cardiovascular events, and weight gain (83-85). There is a correlation between exosomes and traditional

TABLE 3 | The common therapeutic strategies and disadvantages for the DM and its complications.

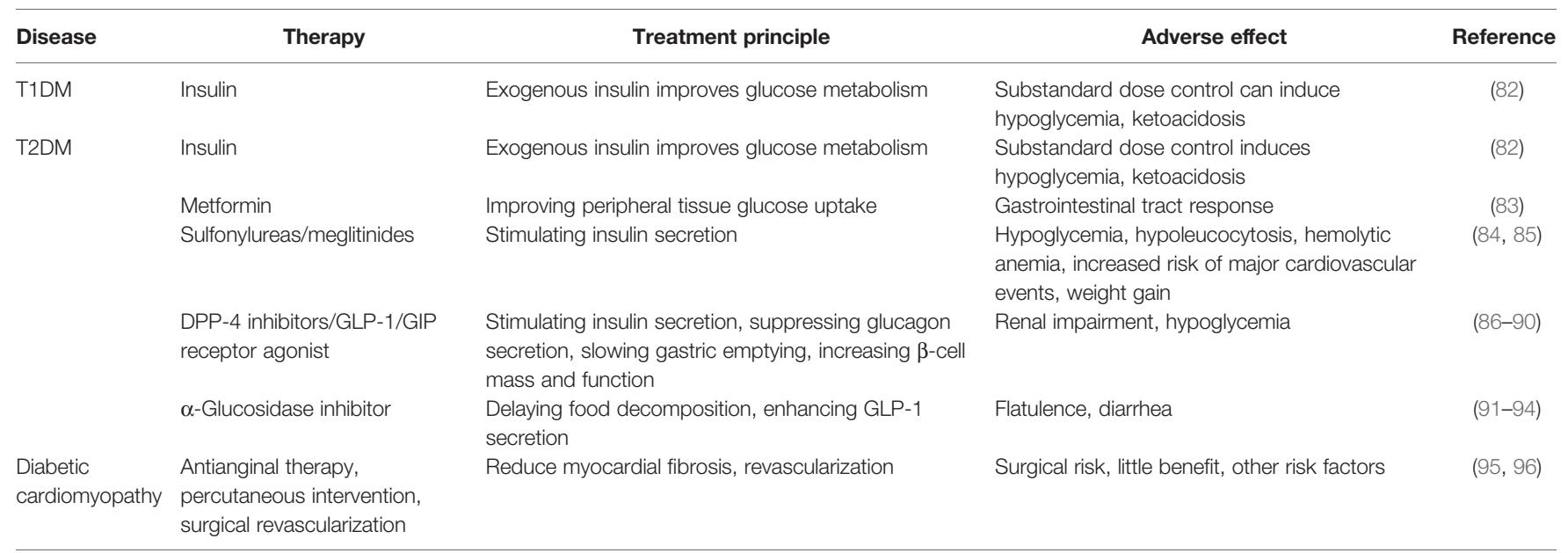

DM, diabetes mellitus; T1DM, type 1 diabetes mellitus; T2DM, type 2 diabetes mellitus. 
diagnostic test results. For example, a study showed that bone marrow mesenchymal stem cell (BM-MSC)-derived exosomes can regulate aging-related insulin resistance. When BM-MSCderived exosomes are administered to old mice, young wild-type C57/BL6J mouse fasting glucose, fasting serum insulin, and HOMA-IR increased, suggesting that BM-MSC-derived exosomes in old mice can damage the body's insulin sensitivity (98). Further clinical data showed that after measuring total plasma and EV-related microRNA (miRNA)-15a by real-time PCR, it was found that the circulating levels of miRNA-15a were significantly different. And miRNA-15a has a significant connection with markers of altered glucose metabolism (e.g., HbA1c, plasma glucose, insulin, and HOMA-IR) (99). However, so far, no specific association mechanism between exosomes and HOMA, fasting glucose, OGTT, HbAlc, and other diagnostic indicators has been found.

Currently, effective drugs to treat diabetic complications are lacking, apart from invasive surgery or conventional methods to relieve symptoms such as anti-inflammatory and wound care $(95,96,100-102)$.

Glycemic control encompasses the management of not only DM but also the associated complications. However, oral hypoglycemic drugs and insulin can only resolve symptoms and cannot prevent disease development. Therefore, novel strategies for effective treatment, which are non-invasive or minimally invasive with minimal or no adverse effects, are urgently required.

\subsection{Cell Transplantation for the Treatment of Diabetes Mellitus and Diabetic Complications: Opportunities and Challenges}

Promoting insulin secretion and ameliorating insulin resistance are the most important approaches in preventing DM and its complications. Pancreas/islet and stem cell transplantations could be effective and have seen remarkable advancements. We discuss the current research on tissue/cell transplantation for the treatment of DM and diabetic complications.

\subsubsection{The Limitations of Pancreas or Islet Transplantation}

Pancreas or islet transplantation has been applied in both T1DM and T2DM and has proved successful in restoring functional $\beta$ cells $(103,104)$. However, even after several years since first use, these have not been applied extensively for the following reasons. 1) Pancreas or islet transplantation requires surgical intervention. Although islet transplantation is minimally invasive, the risk of portal vein hypertension, thrombosis, or infarction of the liver exists (105-107). 2) Post-transplant autoimmune reactions can cause graft loss and eventual failure (108). 3) To reduce donor antigens, using islets from a single donor (>5,600 islets equivalents $/ \mathrm{kg}$ ) is the best approach; however, this cannot meet the demand, and post-transplant management is complex (109). Patients with glucose lability, insulin resistance, obesity, and donor sensitization are not good candidates for islet transplantation (109). To solve these problems, Sui et al. induced nuclear transfer embryonic stem cells (NT-ES) into C-peptide-positive cells and achieved an average efficiency of $55 \%$ in vitro, which indicates that this approach could address the challenges of $\beta$-cell donation. However, the risk of teratomas remains. Sui et al. (110) found that neuropeptide Y (NPY) family members can activate the Y receptor that inhibits glucagon-like peptide 1 (GLP-1) signaling in $\beta$ cells and induces insulin secretion. Using $\mathrm{Y}$ receptor inhibitors can increase insulin secretion from transplanted islets; however, little is known about Y receptor inhibitors (111), which precludes its immediate extensive clinical use.

\subsubsection{The Advantages and Disadvantages of Mesenchymal Stem Cell Transplantation}

Currently, MSCs are regarded as a potent regenerative source in repairing injured tissue $(26,50,112,113)$, including in DM and associated diseases. This hypothesis was verified in both animal models and among patients with diabetes. Human umbilical cord MSC (hucMSC) infusion decreased high-fat diet and streptozotocin (STZ)-induced T2DM in rats. Blood glucose level decrease was affected by increasing insulin sensitivity and restoring insulin secretion (114-116). hucMSC injection can also help decrease insulin dependency in patients with T2DM in early stages and hence reduce the insulin dosage at later stages (117). The characteristics of MSCs such as low immunogenicity, proliferation, and multilineage differentiation may partly solve the challenges associated with pancreas or islet transplantation (118, 119). Moreover, genetic editing techniques such as lentivirus and CRISPER/Cas9 in MSCs, which overexpress exendin-4, can be used for pancreatic duodenal homeobox-1-induced MSC differentiation into insulin secretion cells, which may help overcome the shortage in islet donors $(120,121)$. Besides, MSCs also show remarkable effects in diabetic complications. BM-MSCs seeded in collagen scaffolds can augment angiogenesis in diabetic ulcers in rabbits (122). Placenta-derived MSCs can accelerate foot ulcer repair by inhibiting $\mathrm{NF}-\kappa \mathrm{B}$ expression and promoting secretion of the anti-inflammatory factor IL-10 (123) in T2DM rat models. In diabetic nephropathy, MSCs derived from several tissues can reverse glomerular injury by inhibiting oxidation, proinflammatory cytokines, and macrophage infiltration (124127). MSCs also can reverse diabetic neuropathy, cardiopathy, and retinopathy; the underlying mechanism mainly involves improving revascularization, inhibiting fibrosis, controlling inflammation, and regulating oxidation (128-130). Given this body of evidence, MSCs could be the best treatment choice for diabetes and diabetic complications. However, MSC transplantation also presents challenges. First, in vivo MSC injection has tumorigenic potential (131-136). Second, the infusion of a large number of MSCs may cause thrombosis (137, 138), headache, and fever (139). Third, the low survival time and efficiency of MSCs in vivo may limit their therapeutic efficiency (140). Fourth, although several studies have attempted to improve MSC therapy with techniques such as transfecting CDR1 (141) and hepatocyte nuclear factor-4 alpha (HNF-4 $\alpha)$ to regulate the biological characteristics of MSCs directly (142), no practical strategy is applicable in clinical practice and increases the risk of MSC application. 


\subsection{The Advantages of Exosomes in Regulating the Glucose Metabolism in Diabetes Mellitus and Resolving Diabetic Complications}

Glucose metabolism regulation by exosomes was first discovered in the setting of physical exercise. Physical exercise is critical in DM care and has proved to increase insulin sensitivity in peripheral tissues and preserve $\beta$-cell function $(143,144)$. Physical exercise or training can also induce rapid release of small EVs from skeletal muscle into circulation, which indicates a connection between exercise-induced exosome release and reversal of insulin resistance and $\beta$-cell destruction $(145,146)$. Furthermore, exosomes released by muscles may contribute to DM management. Glucose-deprived cardiomyocytes released exosomes containing glucose transporter 1 (GLUT1) and GLUT4, and other glucose metabolism enzymes, which can increase glucose uptake and subsequent glycolysis in neighboring endothelial cells (147). Exosomes released during exercise contain miR-455, miR-29b, miR-323-5p, and miR-466, which can downregulate the expression of matrix metalloproteinase (MMP9) by binding to its $3^{\prime}$ region to inhibit MMP9-induced cardiac fibrosis, which may reverse diabetic cardiopathy $(15,148)$. Previously, our team has used exosomes derived from hucMSCs to treat T2DM rat models, achieved good curative effects in the early stage, and explained the relevant mechanisms (149). In addition, exosomes secreted from INS-1 cells can deliver neutral ceramidase to inhibit palmitic acid (PA)-induced INS-1 cell apoptosis and increase insulin sensitivity in the PA-induced insulin-resistant cell model H4IIEC3 (150). These data showed the potential of physical exercise associated exosomes in regulating glucose metabolism.

Exosomes have also been reported to be effective in the treatment of diabetic complications. For instance, Davidson et al. found that exosomes derived from diabetic rats are not capable of activing the ERK1/2 and HSP27 cardioprotective pathway to protect rat cardiomyocytes from hypoxia and reoxygenation injury (151); however, exosomes derived from nondiabetic plasma were effective. In addition, human endothelial progenitor cell-derived exosomes contained angiogenesis-related molecules, including FGF-1, VEGFA, VEGFR-2, ANG-1, Eselectin, CXCL-16, eNOS, and IL-8, to accelerate cutaneous wound healing in diabetic rats by improving proliferation, migration, and angiogenic tubule formation in endothelial cells (152); the Erk1/2 signaling pathway was also involved (153). These reports indicate that the contents of exosomes derived from patients with $\mathrm{DM}$ or diabetic complications are dysfunctional and incapable of regulating cell-cell communications; however, the use of exogenous exosomes overcomes these limitations.

GDM is the first occurrence or diagnosis of abnormal glucose tolerance during pregnancy; this condition occurs during pregnancy when the pancreatic $\beta$-cell function is insufficient to overcome the insulin resistance (154). The incidence of GDM is increasing every year (155). It is associated with various shortterm and long-term adverse effects in pregnant women and offspring (156). Early screening and timely intervention are critical to improve the maternal and child outcomes in GDM (157-159). Exosomes can be potential biomarkers for disease diagnosis and early prediction $(160,161)$, can carry miRNA, lncRNA, protein, and so forth, which act on recipient cells (162) and play a key role in intercellular signal transmission (163). Previous studies have found that in different stages of pregnancy, the levels and biological activities of exosomes in the circulation differ between women with GDM and without (164); however, the miRNA expression changes in exosomes in GDM. The underlying mechanisms are yet to be fully clarified. GDM is associated with proinflammatory processes, oxidative stress, and endothelial cell dysfunction in the placental microvascular system (165). Fetal-placental endothelial dysfunction is characterized by changes in the L-arginine-adenosine signaling pathway and inflammation $(165,166)$. The mechanisms involved in these changes are hypothesized to be hyperglycemia, hyperinsulinemia, and oxidative stress $(167,168)$. These conditions increase the release of exosomes. Because exosomes can regulate vascular function, they play an important role in the fetal-placental endothelial dysfunction in pregnancy in women with GDM (165). Increasing evidence shows that miRNAs rich in nanovesicles called exosomes are important regulators of gene expression. Compared with a normal pregnancy, a GDM pregnancy is associated with skeletal muscle insulin resistance and increased levels of circulating placental exosomes. Placental exosomes from women with GDM pregnancy suppressed insulin-stimulated migration and glucose uptake in primary skeletal muscle cells obtained from patients with normal insulin sensitivity. Of interest, placental exosomes from normoglycemic women increased insulin migration and glucose uptake in skeletal muscle of women with diabetes (73).

Although DM and diabetic complications are metabolic diseases, one of the essential causes is tissue injury. For example, auto-antibodies destroy $\beta$ cells, causing insulin secretion deficiency; lipid mediates activation of macrophages to prominent proinflammatory cytokines and induces insulin resistance $(169,170)$; chronic high glucose levels and insulin resistance cause increased fatty acid metabolism; the reduced myofilament $\mathrm{Ca}^{+}$sensitivity, mitochondrial dysfunction, oxidative stress, apoptosis, and fibrosis induce endothelial cell apoptosis, cardiomyopathy (30, 31, 34-36), and neuropathy; and chronic high glucose levels and working strength induce glomerular injury and renal fibrosis $(29,76)$. Based on reported evidence, exosomes can potentially repair tissue injury.

\subsection{Therapeutic Advantages of Mesenchymal Stem Cell-Derived Exosomes in Diabetes Mellitus and Diabetic Complications}

Exosomes can be derived from several tissues and cells; however, exosomes can be derived from MSCs (MSC-ex) most conveniently. MSCs can be isolated from the bone marrow, umbilical cord, and adipose tissue, which can be used in autotransplantation. Low immunogenicity ensures low 
immunoreactions in such transplantation. The proliferation potential of MScs ensures sufficiency of exosomes.

Currently, the repair of injured tissue by MSCs does not rely on proliferation potential but on paracrine activity, because only $<1 \%$ MSCs can reach the target tissue, and evidence shows that MSCs differentiated into target cells are lacking (114, 171-173). Exosomes are one of the most important approaches for paracrine regulation. Our previous research showed that exosomes are an excellent replacement for MSCs and played an important role in the repair of injured tissue or organs by delivering bioactive molecules such as Wnt4 (7) and Wnt11 to regulate $\beta$-catenin and ameliorate scalded wound, and 14-3-3 $\zeta$ and glutathione peroxidase 1 to regulate YAP signaling in inhibiting excessive repair and recovering hepatic oxidant injury $(8,50,112)$. MSC-ex can also mediate the repair of osteochondral defects by increasing cellular proliferation and infiltration, enhancing matrix synthesis, and a regenerative immune phenotype (174). The present studies not only explain the mechanism underlying MSC-driven repair of tissue injury but also prove that exosomes are key to the paracrine activity of MSCs.

In DM, MSC-ex could be the key element in protecting the pancreatic islets in patients with T1DM from autoimmune targeting, slowing disease progression (175). MSC-ex can promote angiogenesis and survival of transplanted pancreatic islets and can enhance the efficiency and success rate of the treatment, for example, by carrying siFas and anti-miR-375 and inhibiting immune reaction to improve islet transplantation $(176,177)$. MiR-29b-3p in MSC-derived exosomes significantly ameliorated the insulin resistance in aged mice and helped regulate the blood glucose level (98). Exosomes from the hucMSCs can downregulate blood glucose level in T2DM by reversing peripheral insulin resistance and inhibiting $\beta$-cell destruction (149). In diabetic complications, MSC-ex can induce proliferation and migration of normal and chronic wound fibroblasts and enhance angiogenesis to accelerate cutaneous wound healing (178). Diabetes-induced cognitive impairment and nephropathy can be improved by bone marrow stem cell-derived exosomes too $(179,180)$.

Besides ordinary MSC-ex, exosomes from modified MSCs can carry special molecules, like exosomes from $3,3^{\prime}$ diindolylmethane (DIM)-stimulated human hucMSCs contain higher levels of Wnt 11 and enhanced the wound healing potential of hucMSCs (112). Exosomes from hypoxia-inducible factor $1 \alpha$ (HIF-1 $\alpha)$ modified BM-MSCs were much more effective in attenuating early steroid-induced avascular necrosis of the femoral head in rabbits than exosomes from the wild-type MSCs (181). These studies indicate that the potency of exosomes can be increased by modifying MSCs, which may be safer than using MSCs directly and can promote the use of exosomes in the treatment of DM and diabetic complications (Figure 2).

\subsection{The Utility of Exosomes in Other Diseases}

As a communication messenger between cells, the potential role of exosomes in the clinical treatment and prevention of diseases has gradually emerged. First, in early diagnosis or targeted tumor treatment, various tumor-derived exosomes have been identified that harbor several specific molecules from different types of tumors in patients with cancer $(182,183)$. In addition, exosomes are associated with neurodegenerative diseases, such as Alzheimer's disease (AD) and Parkinson's disease. A recent study found that $\mathrm{AD}$ caused by the accumulation of $\beta$-amyloid $(\mathrm{A} \beta)$ peptides in senile plaques is related to an exosomeassociated protein called ALIX, which suggests a significant role of exosomes in the pathogenesis of AD (184). Exosomes can participate in the occurrence and development of cardiovascular diseases. Scientists found that exosomes carrying endothelial differentiation signals affect the formation of new blood vessels, indicating the effectiveness of exosomes in the treatment of angiogenesis $(185,186)$. In addition, our findings indicated that DIM promoted the stemness of hucMSCs by increasing exosomes derived from hucMSCs to activate Wnt11 autocrine signaling, which provides a novel strategy for improving the therapeutic effects of hucMSCs on skin wound healing (112).

Some studies have shown that exosomes derived from MSCs can also increase ATP levels, reduce oxidative stress through the PI3K/Akt pathway, enhance the vitality of myocardial cells, and prevent adverse remodeling after myocardial ischemia and reperfusion (187). In a study of intervertebral disc degeneration, exosomes can significantly inhibit the inflammatory response of apoptotic nucleus pulposus cells (188).

Exosomes are also involved in the occurrence and development of liver diseases. Karamichali et al. found that exosomes can mediate the transfer of in-frame deletion mutants to regulate $\mathrm{HCV}$ virus replication and make the virus continue to infect (189). The concentration of exosomes in the peripheral blood of pregnant women is closely related to the process of pregnancy and pregnancy complications. Abnormal concentration of exosomes in the peripheral blood of pregnant women can reflect the risk of pregnancy complications to a certain extent (190).

\subsection{The Future Application Prospects of Exosomes in the Treatment of Diabetes and Complications}

Nowadays, the application of MSC exosomes is becoming more and more extensive, and the corresponding application technology is relatively mature. In autologous therapy, currently, the main cell-free therapy is MSC-ex. It contains a variety of functional proteins, mRNAs, miRNAs, and signaling lipids (191-193). In non-autologous therapy, researchers are moving towards a new strategy based on loading MSC-ex by patches, injectable microcarriers, or hydrogels, aimed at maintaining the function of exosomes at the function site and enhancing efficiency and safety. Chitosan and relevant compounds are ideal carriers for the sustained release of nanoparticles including exosomes (183, 194, 195). Shi et al. prepared the chitosan/silk hydrogel sponge by freeze-drying method to be a scaffold for exosomes (196). Since chitosan is a hydrophilic polymer, this hydrogel sponge shows good swelling behavior, creates a moist environment, and enhances the angiogenesis and neuronal ingrowth. Alginate- 


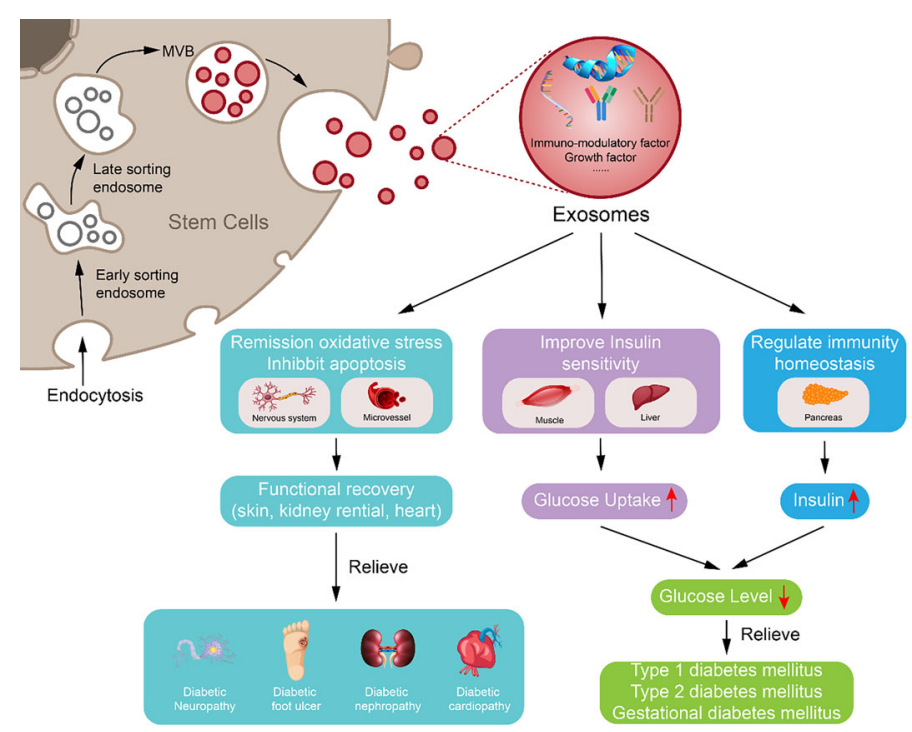

FIGURE 2 | Potential approach of exosomes derived from mesenchymal stem cell in diabetes mellitus and diabetic complication repair. Exosome derived from mesenchymal stem cell may downregulate blood glucose through reversing peripheral tissue (liver and muscle) insulin resistance and increasing $\beta$-cell survival during remission of diabetes mellitus; exosome derived from mesenchymal stem cell can inhibit apoptosis, oxidative stress, and immune reaction to reduce vascular or neuron injury and carry growth factors to increase damaged tissue or cell repair, which may participate in alleviating diabetic complications.

based hydrogels have been designed to encapsulate adiposederived mesenchymal stem cell exosomes (ADSC-Exos) to fabricate a bioactive scaffold (133), which is tested to be biodegradable and biocompatible, reflecting its potential as a cell-free therapy (197). In general, the exosome-carrier compound displays better treatment outcomes than the exosomes or carrier materials alone, suggesting a synergistic effect through the sustained release of MSC-ex. Not only that, for better delivery of exosomes, MSC exosomes that deliver biological scaffolds have also been invented and used and were fabricated in a 3D-printed cartilage extracellular matrix (ECM)/ gelatin methacrylate (GelMA)/exosome scaffold (198).

Besides, in the future, with the help of mass spectrometry and high-throughput sequencing $(199,200)$, a pathological molecular spectrum of exosomes derived from body fluids of diabetic patients will be formed, covering molecules such as proteins, nucleic acids, and metabolites, which can provide new ideas and research for early diagnosis and prognosis of diabetes. This direction can also provide more options for the treatment of diseases.

\section{SUMMARY}

Exosomes can function not only as biomarkers for early diagnosis of DM but also as potential therapeutic tools in DM and its complications. However, some key challenges exist. The cost of exosome isolation for high volume use is high; no diagnostic and therapeutic standards have been established; and most supporting studies were animal model studies.
Further study is needed before extensive clinical use of exosomes can be recommended.

\section{AUTHOR CONTRIBUTIONS}

YS and QT: conception and design, collection and/or assembly of data, data analysis and interpretation, visualization, manuscript writing, and final approval of the manuscript; these authors contributed equally to this work. XW: collection and/or assembly of data. LZ: collection and/or assembly of data. QL and LW: conception and design, financial support, administrative support, provision of study material, supervision, collection and/or assembly of data, data analysis and interpretation, visualization, manuscript writing, and final approval of the manuscript. All authors reviewed the manuscript. All authors contributed to the article and approved the submitted version.

\section{FUNDING}

This work was supported by the Natural Science Youth Foundation of the Jiangsu Province (Grant BK20210074), the Introduction program of high-level innovative and entrepreneurial talents in Jiangsu province, Wuxi first "Double hundred" Young and middle-aged Top-notch Medical and health talents Program (HB2020108), Wuxi Health Commission scientific research project youth project (Q202059), and the National Key R\&D Program of China (2020YFC2005300). 


\section{REFERENCES}

1. Pan B-T, Johnstone RM. Fate of the Transferrin Receptor During Maturation of Sheep Reticulocytes In Vitro: Selective Externalization of the Receptor. Cell (1983) 33(3):967-78. doi: 10.1016/0092-8674(83)90040-5

2. Almughlliq FB, Koh YQ, Peiris HN, Vaswani K, Holland O, Meier S, et al. Circulating Exosomes may Identify Biomarkers for Cows at Risk for Metabolic Dysfunction. Sci Rep (2019) 9(1):1-12. doi: 10.1038/s41598019-50244-7

3. Han Y, Jia L, Zheng Y, Li W. Salivary Exosomes: Emerging Roles in Systemic Disease. Int J Biol Sci (2018) 14(6):633. doi: 10.7150/ijbs.25018

4. Li L, Zhang Y, Mu J, Chen J, Zhang C, Cao H, et al. Transplantation of Human Mesenchymal Stem Cell-Derived Exosomes Immobilized in An Adhesive Hydrogel for Effective Treatment of Spinal Cord Injury. Nano Lett (2020) 20(6):4298-305. doi: 10.1021/acs.nanolett.0c00929

5. Whitham M, Parker BL, Friedrichsen M, Hingst JR, Hjorth M, Hughes WE, et al. Extracellular Vesicles Provide a Means for Tissue Crosstalk During Exercise. Cell Metab (2018) 27(1):237-51.e4. doi: 10.1016/ j.cmet.2017.12.001

6. Qin Y, Peng Y, Zhao W, Pan J, Ksiezak-Reding H, Cardozo C, et al. Myostatin Inhibits Osteoblastic Differentiation by Suppressing OsteocyteDerived Exosomal microRNA-218: A Novel Mechanism in Muscle-Bone Communication. J Biol Chem (2017) 292(26):11021-33. doi: 10.1074/ jbc.M116.770941

7. Zhang B, Wang M, Gong A, Zhang X, Wu X, Zhu Y, et al. HucMSCExosome Mediated-Wnt4 Signaling Is Required for Cutaneous Wound Healing. Stem Cells (2015) 33(7):2158-68. doi: 10.1002/stem.1771

8. Yan Y, Jiang W, Tan Y, Zou S, Zhang H, Mao F, et al. hucMSC ExosomeDerived GPX1 Is Required for the Recovery of Hepatic Oxidant Injury. Mol Ther (2017) 25(2):465-79. doi: 10.1016/j.ymthe.2016.11.019

9. Jiang N, Xiang L, He L, Yang G, Zheng J, Wang C, et al. Exosomes Mediate Epithelium-Mesenchyme Crosstalk in Organ Development. ACS Nano (2017) 11(8):7736-46. doi: 10.1021/acsnano.7b01087

10. Raposo G, Stoorvogel W. Extracellular Vesicles: Exosomes, Microvesicles, and Friends. J Cell Biol (2013) 200(4):373-83. doi: 10.1083/jcb.201211138

11. Liu M-L, Reilly MP, Casasanto P, McKenzie SE, Williams KJ. Cholesterol Enrichment of Human Monocyte/Macrophages Induces Surface Exposure of Phosphatidylserine and the Release of Biologically-Active Tissue FactorPositive Microvesicles. Arteriosc Thromb Vasc Biol (2007) 27(2):430-5. doi: 10.1161/01.ATV.0000254674.47693.e8

12. Li M, Yu D, Williams KJ, Liu M-L. Tobacco Smoke Induces the Generation of Procoagulant Microvesicles From Human Monocytes/Macrophages. Arteriosc Thromb Vasc Biol (2010) 30(9):1818-24. doi: 10.1161/ ATVBAHA.110.209577

13. Théry C, Zitvogel L, Amigorena S. Exosomes: Composition, Biogenesis and Function. Nat Rev Immunol (2002) 2(8):569-79. doi: 10.1038/nri855

14. Zhang X, Yuan X, Shi H, Wu L, Qian H, Xu W. Exosomes in Cancer: Small Particle, Big Player. J Hematol Oncol (2015) 8(1):83. doi: 10.1186/s13045014-0103-3

15. Gonzalez E, Falcón-Pérez JM. Cell-Derived Extracellular Vesicles as a Platform to Identify Low-Invasive Disease Biomarkers. Expert Rev Mol Diagnostics (2015) 15(7):907-23. doi: 10.1586/14737159.2015.1043272

16. Tavasolian F, Moghaddam AS, Rohani F, Abdollahi E, Janzamin E, Momtazi-Borojeni AA, et al. Exosomes: Effectual Players in Rheumatoid Arthritis. Autoimmun Rev (2020) 19(6):102511. doi: 10.1016/ j.autrev.2020.102511

17. Chen S, He R, He B, Xu L, Zhang S. Potential Roles of Exosomal IncRNAs in the Intestinal Mucosal Immune Barrier. J Immunol Res (2021) 2021. doi: $10.1155 / 2021 / 7183136$

18. Simpson RJ, Lim JW, Moritz RL, Mathivanan S. Exosomes: Proteomic Insights and Diagnostic Potential. Expert Rev Proteomics (2009) 6(3):26783. doi: $10.1586 /$ epr.09.17

19. Liu Z, Xu Y, Wan Y, Gao J, Chu Y, Li J. Exosomes From Adipose-Derived Mesenchymal Stem Cells Prevent Cardiomyocyte Apoptosis Induced by Oxidative Stress. Cell Death Discov (2019) 5(1):1-7. doi: 10.1038/s41420019-0159-5

20. Zhang B, Wu X, Zhang X, Sun Y, Yan Y, Shi H, et al. Human Umbilical Cord Mesenchymal Stem Cell Exosomes Enhance Angiogenesis Through the
Wnt4/B-Catenin Pathway. Stem Cells Trans Med (2015) 4(5):513-22. doi 10.5966/sctm.2014-0267

21. Tang Y-T, Huang Y-Y, Zheng L, Qin S-H, Xu X-P, An T-X, et al. Comparison of Isolation Methods of Exosomes and Exosomal RNA From Cell Culture Medium and Serum. Int J Mol Med (2017) 40(3):834-44. doi: 10.3892/ijmm.2017.3080

22. Melo SA, Sugimoto H, O'Connell JT, Kato N, Villanueva A, Vidal A, et al. Cancer Exosomes Perform Cell-Independent microRNA Biogenesis and Promote Tumorigenesis. Cancer Cell (2014) 26(5):707-21. doi: 10.1016/ j.ccell.2014.09.005

23. Melo SA, Luecke LB, Kahlert C, Fernandez AF, Gammon ST, Kaye J, et al. Glypican-1 Identifies Cancer Exosomes and Detects Early Pancreatic Cancer. Nature (2015) 523(7559):177-82. doi: 10.1038/nature14581

24. Beckham CJ, Olsen J, Yin P-N, Wu C-H, Ting H-J, Hagen FK, et al. Bladder Cancer Exosomes Contain EDIL-3/Del1 and Facilitate Cancer Progression. J Urol (2014) 192(2):583-92. doi: 10.1016/j.juro.2014.02.035

25. Konadu KA, Huang MB, Roth W, Armstrong W, Powell M, Villinger F, et al. Isolation of Exosomes From the Plasma of HIV-1 Positive Individuals. J Visualized Exp (2016) 107):e53495. doi: 10.3791/53495

26. Zhou Y, Xu H, Xu W, Wang B, Wu H, Tao Y, et al. Exosomes Released by Human Umbilical Cord Mesenchymal Stem Cells Protect Against CisplatinInduced Renal Oxidative Stress and Apoptosis In Vivo and In Vitro. Stem Cell Res Ther (2013) 4(2):1-13. doi: 10.1186/scrt194

27. Tian T, Zhang H-X, He C-P, Fan S, Zhu Y-L, Qi C, et al. Surface Functionalized Exosomes as Targeted Drug Delivery Vehicles for Cerebral Ischemia Therapy. Biomaterials (2018) 150:137-49. doi: 10.1016/ j.biomaterials.2017.10.012

28. Roglic G. Organization WH. Global Report on Diabetes. Geneva, Switzerland: World Health Organization (2016).

29. Bălăşescu E, Ion DA, Cioplea M, Zurac S. Caspases, Cell Death and Diabetic Nephropathy. Romanian J Internal Med (2015) 53(4):296-303. doi: 10.1515/ rjim-2015-0038

30. Mohamed Q, Gillies MC, Wong TY. Management of Diabetic Retinopathy: A Systematic Review. JAMA (2007) 298(8):902-16. doi: 10.1001/jama. 298.8.902

31. Rebolledo FA, Soto JT, de la Peña JE. The Pathogenesis of the Diabetic Foot Ulcer: Prevention and Management. Global Perspective Diabetic Foot Ulcerations (2011) p:155-78. doi: 10.5772/30325

32. Nyenwe EA, Jerkins TW, Umpierrez GE, Kitabchi AE. Management of Type 2 Diabetes: Evolving Strategies for the Treatment of Patients With Type 2 Diabetes. Metabolism (2011) 60(1):1-23. doi: 10.1016/j.metabol. 2010.09.010

33. John W. Use of HbAlc in the Diagnosis of Diabetes Mellitus in the UK. The Implementation of World Health Organization Guidance 2011. Diabetic medicine: J Br Diabetic Assoc (2012) 29(11):1350. doi: 10.1111/j.14645491.2012.03762.x

34. Xu H, Barnes GT, Yang Q, Tan G, Yang D, Chou CJ, et al. Chronic Inflammation in Fat Plays a Crucial Role in the Development of ObesityRelated Insulin Resistance. J Clin Invest (2003) 112(12):1821-30. doi 10.1172/JCI200319451

35. Bhatt NM, Aon MA, Tocchetti CG, Shen X, Dey S, Ramirez-Correa G, et al. Restoring Redox Balance Enhances Contractility in Heart Trabeculae From Type 2 Diabetic Rats Exposed to High Glucose. Am J Physiol Heart Circulatory Physiol (2015) 308(4):H291-302. doi: 10.1152/ajpheart. 00378.2014

36. Ward M-L, Crossman DJ. Mechanisms Underlying the Impaired Contractility of Diabetic Cardiomyopathy. World J Cardiol (2014) 6 (7):577. doi: 10.4330/wjc.v6.i7.577

37. Amaral N, Okonko DO. Metabolic Abnormalities of the Heart in Type II Diabetes. Diabetes Vasc Dis Res (2015) 12(4):239-48. doi: 10.1177/ 1479164115580936

38. Sun A-L, Deng J-t, Guan G-j, Chen S-h, Liu Y-t, Cheng J, et al. Dipeptidyl Peptidase-IV Is a Potential Molecular Biomarker in Diabetic Kidney Disease. Diabetes Vasc Dis Res (2012) 9(4):301-8. doi: 10.1177/1479164111434318

39. Tanaka Y, Kamohara H, Kinoshita K, Kurashige J, Ishimoto T, Iwatsuki M, et al. Clinical Impact of Serum Exosomal microRNA-21 as a Clinical Biomarker in Human Esophageal Squamous Cell Carcinoma. Cancer (2013) 119(6):1159-67. doi: 10.1002/cncr.27895 
40. Martínez MC, Andriantsitohaina R. Extracellular Vesicles in Metabolic Syndrome. Circ Res (2017) 120(10):1674-86. doi: 10.1161/CIRCRESAHA. 117.309419

41. Safdar A, Saleem A, Tarnopolsky MA. The Potential of Endurance ExerciseDerived Exosomes to Treat Metabolic Diseases. Nat Rev Endocrinol (2016) 12(9):504. doi: 10.1038/nrendo.2016.76

42. Gao X, Wan Z, Wei M, Dong Y, Zhao Y, Chen X, et al. Chronic Myelogenous Leukemia Cells Remodel the Bone Marrow Niche via Exosome-Mediated Transfer of miR-320. Theranostics (2019) 9(19):5642. doi: 10.7150/ thno. 34813

43. Riazifar M, Mohammadi MR, Pone EJ, Yeri A, Lasser C, Segaliny AI, et al. Stem Cell-Derived Exosomes as Nanotherapeutics for Autoimmune and Neurodegenerative Disorders. ACS Nano (2019) 13(6):6670-88. doi: 10.1021/acsnano.9b01004

44. Zhao H, Shang Q, Pan Z, Bai Y, Li Z, Zhang H, et al. Exosomes From Adipose-Derived Stem Cells Attenuate Adipose Inflammation and Obesity Through Polarizing M2 Macrophages and Beiging in White Adipose Tissue. Diabetes (2018) 67(2):235-47. doi: 10.2337/db17-0356

45. Markowska A, Pendergrast RS, Pendergrast JS, Pendergrast PS. A Novel Method for the Isolation of Extracellular Vesicles and RNA From Urine. J Circ Biomark (2017) 6:1849454417712666. doi: 10.1177/ 1849454417712666

46. Iwai K, Yamamoto S, Yoshida M, Shiba K. Isolation of Extracellular Vesicles in Saliva Using Density Gradient Ultracentrifugation. In: Extracellular Vesicles. J Extracell Vesicles. Germany: Springer (2017). p. 343-50.

47. Kenigsberg S, Wyse BA, Librach CL, da Silveira JC. Protocol for Exosome Isolation From Small Volume of Ovarian Follicular Fluid: Evaluation of Ultracentrifugation and Commercial Kits. In: Extracellular Vesicles. J Extracell Vesicles. Germany: Springer (2017). p. 321-41.

48. Puhka M, Takatalo M, Nordberg M-E, Valkonen S, Nandania J, Aatonen M, et al. Metabolomic Profiling of Extracellular Vesicles and Alternative Normalization Methods Reveal Enriched Metabolites and Strategies to Study Prostate Cancer-Related Changes. Theranostics (2017) 7(16):3824. doi: 10.7150/thno. 19890

49. Oksvold MP, Neurauter A, Pedersen KW. Magnetic Bead-Based Isolation of Exosomes. RNA Interference (2015) 1218:465-81. doi: 10.1007/978-1-49391538-5_27

50. Zhang B, Shi Y, Gong A, Pan Z, Shi H, Yang H, et al. HucMSC ExosomeDelivered 14-3-3 $\zeta$ Orchestrates Self-Control of the Wnt Response via Modulation of YAP During Cutaneous Regeneration. Stem Cells (2016) 34 (10):2485-500. doi: 10.1002/stem.2432

51. Lai X, Wang M, McElyea SD, Sherman S, House M, Korc M. A microRNA Signature in Circulating Exosomes Is Superior to Exosomal Glypican-1 Levels for Diagnosing Pancreatic Cancer. Cancer Lett (2017) 393:86-93. doi: 10.1016/j.canlet.2017.02.019

52. Batrakova EV, Kim MS. Using Exosomes, Naturally-Equipped Nanocarriers, for Drug Delivery. J Control Release (2015) 219:396-405. doi: 10.1016/ j.jconrel.2015.07.030

53. Murakami T, Oakes M, Ogura M, Tovar V, Yamamoto C, Mitsuhashi M. Development of Glomerulus-, Tubule-, and Collecting Duct-Specific mRNA Assay in Human Urinary Exosomes and Microvesicles. PloS One (2014) 9 (10):e109074. doi: 10.1371/journal.pone.0109074

54. Dragovic R, Collett G, Hole P, Ferguson D, Redman C, Sargent I, et al. Isolation of Syncytiotrophoblast Microvesicles and Exosomes and Their Characterisation by Multicolour Flow Cytometry and Fluorescence Nanoparticle Tracking Analysis. Methods (2015) 87:64-74. doi: 10.1016/ j.ymeth.2015.03.028

55. Rim K-T, Kim S-J. Quantitative Analysis of Exosomes From Murine Lung Cancer Cells by Flow Cytometry. J Cancer Prev (2016) 21(3):194. doi: 10.15430/JCP.2016.21.3.194

56. Weng Y, Sui Z, Shan Y, Hu Y, Chen Y, Zhang L, et al. Effective Isolation of Exosomes With Polyethylene Glycol From Cell Culture Supernatant for inDepth Proteome Profiling. Analyst (2016) 141(15):4640-6. doi: 10.1039/ C6AN00892E

57. Sabatier F, Darmon P, Hugel B, Combes V, Sanmarco M, Velut J-G, et al. Type 1 and Type 2 Diabetic Patients Display Different Patterns of Cellular Microparticles. Diabetes (2002) 51(9):2840-5. doi: 10.2337/diabetes. 51.9.2840
58. Li S, Wei J, Zhang C, Li X, Meng W, Mo X, et al. Cell-Derived Microparticles in Patients With Type 2 Diabetes Mellitus: A Systematic Review and MetaAnalysis. Cell Physiol Biochem (2016) 39(6):2439-50. doi: 10.1159/ 000452512

59. Burger D, Turner M, Xiao F, Munkonda MN, Akbari S, Burns KD. High Glucose Increases the Formation and Pro-Oxidative Activity of Endothelial Microparticles. Diabetologia (2017) 60(9):1791-800. doi: 10.1007/s00125017-4331-2

60. Abe H, Sakurai A, Ono H, Hayashi S, Yoshimoto S, Ochi A, et al. Urinary Exosomal mRNA of WT1 as Diagnostic and Prognostic Biomarker for Diabetic Nephropathy. J Med Invest (2018) 65(3.4):208-15. doi: 10.2152/ jmi.65.208

61. Zubiri I, Posada-Ayala M, Sanz-Maroto A, Calvo E, Martin-Lorenzo M, Gonzalez-Calero L, et al. Diabetic Nephropathy Induces Changes in the Proteome of Human Urinary Exosomes as Revealed by Label-Free Comparative Analysis. J Proteomics (2014) 96:92-102. doi: 10.1016/ j.jprot.2013.10.037

62. Barutta F, Tricarico M, Corbelli A, Annaratone L, Pinach S, Grimaldi S, et al. Urinary Exosomal microRNAs in Incipient Diabetic Nephropathy. PloS One (2013) 8(11):e73798. doi: 10.1371/journal.pone.0073798

63. Sharma K, Karl B, Mathew AV, Gangoiti JA, Wassel CL, Saito R, et al. Metabolomics Reveals Signature of Mitochondrial Dysfunction in Diabetic Kidney Disease. J Am Soc Nephrol (2013) 24(11):1901-12. doi: 10.1681/ ASN.2013020126

64. Sakurai A, Ono H, Ochi A, Matsuura M, Yoshimoto S, Kishi S, et al. Involvement of Elf3 on Smad3 Activation-Dependent Injuries in Podocytes and Excretion of Urinary Exosome in Diabetic Nephropathy. PloS One (2019) 14(5):e0216788. doi: 10.1371/journal.pone.0216788

65. Lange T, Stracke S, Rettig R, Lendeckel U, Kuhn J, Schlüter R, et al. Identification of miR-16 as an Endogenous Reference Gene for the Normalization of Urinary Exosomal miRNA Expression Data From CKD Patients. PloS One (2017) 12(8):e0183435. doi: 10.1371/ journal.pone. 0183435

66. Gudehithlu KP, Garcia-Gomez I, Vernik J, Brecklin C, Kraus M, Cimbaluk DJ, et al. In Diabetic Kidney Disease Urinary Exosomes Better Represent Kidney Specific Protein Alterations Than Whole Urine. Am J Nephrol (2015) 42(6):418-24. doi: 10.1159/000443539

67. Wang X, Gu H, Huang W, Peng J, Li Y, Yang L, et al. Hsp20-Mediated Activation of Exosome Biogenesis in Cardiomyocytes Improves Cardiac Function and Angiogenesis in Diabetic Mice. Diabetes (2016) 65(10):311128. doi: $10.2337 / \mathrm{db} 15-1563$

68. Wang X, Huang W, Liu G, Cai W, Millard RW, Wang Y, et al. Cardiomyocytes Mediate Anti-Angiogenesis in Type 2 Diabetic Rats Through the Exosomal Transfer of miR-320 Into Endothelial Cells. J Mol Cell Cardiol (2014) 74:139-50. doi: 10.1016/j.yjmcc.2014.05.001

69. Prattichizzo F, Giuliani A, De Nigris V, Pujadas G, Çeka A, La Sala L, et al. Extracellular microRNAs and Endothelial Hyperglycaemic Memory: A Therapeutic Opportunity? Diabetes Obes Metab (2016) 18(9):855-67. doi: 10.1111/dom. 12688

70. Wan S, Wang J, Wang J, Wu J, Song J, Zhang C-Y, et al. Increased Serum miR-7 Is a Promising Biomarker for Type 2 Diabetes Mellitus and Its Microvascular Complications. Diabetes Res Clin Pract (2017) 130:171-9. doi: 10.1016/j.diabres.2017.06.005

71. Schara K, Štukelj R, Krek J, Lakota K, Sodin-Šemrl S, Boulton A, et al. A Study of Extracellular Vesicle Concentration in Active Diabetic Charcot Neuroarthropathy. Eur J Pharm Sci (2017) 98:58-63. doi: 10.1016/ j.ejps.2016.09.009

72. Ju R, Zhuang ZW, Zhang J, Lanahan AA, Kyriakides T, Sessa WC, et al. Angiopoietin-2 Secretion by Endothelial Cell Exosomes: Regulation by the Phosphatidylinositol 3-Kinase (PI3K)/Akt/endothelial Nitric Oxide Synthase (eNOS) and Syndecan-4/Syntenin Pathways. J Biol Chem (2014) 289(1):510-9. doi: 10.1074/jbc.M113.506899

73. Nair S, Jayabalan N, Guanzon D, Palma C, Scholz-Romero K, Elfeky O, et al. Human Placental Exosomes in Gestational Diabetes Mellitus Carry a Specific Set of miRNAs Associated With Skeletal Muscle Insulin Sensitivity. Clin Sci (Lond) (2018) 132(22):2451-67. doi: 10.1042/CS20180487

74. Jansen F, Yang X, Franklin BS, Hoelscher M, Schmitz T, Bedorf J, et al. High Glucose Condition Increases NADPH Oxidase Activity in Endothelial 
Microparticles That Promote Vascular Inflammation. Cardiovasc Res (2013) 98(1):94-106. doi: 10.1093/cvr/cvt013

75. Monteiro LJ, Varas-Godoy M, Monckeberg M, Realini O, Hernández M, Rice G, et al. Oral Extracellular Vesicles in Early Pregnancy can Identify Patients at Risk of Developing Gestational Diabetes Mellitus. PloS One (2019) 14(6):e0218616. doi: 10.1371/journal.pone.0218616

76. Lytvyn Y, Xiao F, Kennedy CR, Perkins BA, Reich HN, Scholey JW, et al. Assessment of Urinary Microparticles in Normotensive Patients With Type 1 Diabetes. Diabetologia (2017) 60(3):581-4. doi: 10.1007/s00125-016-4190-2

77. Li W, Jin L-y, Cui Y-b, Xie N. Human Umbilical Cord Mesenchymal Stem Cells-Derived Exosomal microRNA-17-3p Ameliorates Inflammatory Reaction and Antioxidant Injury of Mice With Diabetic Retinopathy via Targeting STAT1. Int Immunopharmacol (2021) 90:107010. doi: 10.1016/ j.intimp.2020.107010

78. Khare D, Poe A, Shah R, Ljubimov AV, Saghizadeh M. Differential Regulatory Role of Normal and Diabetic Limbal Epithelial Cell-Derived Exosomes in Limbal Stromal Cells. Investig Ophthalmol Vis Sci (2021) 62 (8):756-6.

79. Liu J, Wang J, Fu W, Wang X, Chen H, Wu X, et al. MiR-195-5p and miR205-5p in Extracellular Vesicles Isolated From Diabetic Foot Ulcer Wound Fluid Decrease Angiogenesis by Inhibiting VEGFA Expression. Aging (Albany NY) (2021) 13(15):19805. doi: 10.18632/aging.203393

80. Li Y, Lin S, Xie X, Zhu H, Fan T, Wang S. Highly Enriched Exosomal IncRNA OIP5-AS1 Regulates Osteosarcoma Tumor Angiogenesis and Autophagy Through miR-153 and ATG5. Am J Trans Res (2021) 13(5):4211.

81. Flores-Gonzalez J, Cancino-Díaz JC, Chavez-Galan L. Flow Cytometry: From Experimental Design to Its Application in the Diagnosis and Monitoring of Respiratory Diseases. Int J Mol Sci (2020) 21(22):8830. doi: $10.3390 / \mathrm{ijms} 21228830$

82. Thalange N, Aldhouse NVJ, Kitchen H, Howard D, Tutkunkardas D, Håkan-Bloch J. Healthcare Resource Utilization and Costs Associated With Ketosis Events in Pediatric and Adult Patients With Type 1 Diabetes Mellitus in the UK. Diabetes Ther (2017) 8(5):1065-78. doi: 10.1007/s13300017-0305-0

83. DePeralta DK, Wei L, Ghoshal S, Schmidt B, Lauwers GY, Lanuti M, et al. Metformin Prevents Hepatocellular Carcinoma Development by Suppressing Hepatic Progenitor Cell Activation in a Rat Model of Cirrhosis. Cancer (2016) 122(8):1216-27. doi: 10.1002/cncr.29912

84. Roumie CL, Hung AM, Greevy RA, Grijalva CG, Liu X, Murff HJ, et al. Comparative Effectiveness of Sulfonylurea and Metformin Monotherapy on Cardiovascular Events in Type 2 Diabetes Mellitus: A Cohort Study. Ann Internal Med (2012) 157(9):601-10. doi: 10.7326/0003-4819-157-9201211060-00003

85. Nauck M. Sitagliptin Study 024 Group. Efficacy and Safety of the Dipeptidyl Peptidase-4 Inhibitor, Sitagliptin, Compared With the Sulfonylurea, Glipizide, in Patients With Type 2 Diabetes Inadequately Controlled on Metformin Alone: A Randomized, Double-Blind, Non-Inferiority Trial. Diabetes Obes Metab (2007) 9:194-205. doi: 10.1111/j.14631326.2006.00704.x

86. Matsuyama T, Komatsu R, Namba M, Watanabe N, Itoh H, Tarui S. Glucagon-Like Peptide-1 (7-36 Amide): A Potent Glucagonostatic and Insulinotropic Hormone. Diabetes Res Clin Pract (1988) 5(4):281-4. doi: 10.1016/S0168-8227(88)80063-9

87. Wettergren A, Schjoldager B, Mortensen PE, Myhre J, Christiansen J, Holst JJ. Truncated GLP-1 (Proglucagon 78-107-Amide) Inhibits Gastric and Pancreatic Functions in Man. Digest Dis Sci (1993) 38(4):665-73. doi: 10.1007/BF01316798

88. Tourrel C, Bailbé D, Meile M-J, Kergoat M, Portha B. Glucagon-Like Peptide- 1 and Exendin-4 Stimulate $\beta$-Cell Neogenesis in StreptozotocinTreated Newborn Rats Resulting in Persistently Improved Glucose Homeostasis at Adult Age. Diabetes (2001) 50(7):1562-70. doi: 10.2337/ diabetes.50.7.1562

89. Perfetti R, Zhou J, Doyle M, Egan JM. Glucagon-Like Peptide-1 Induces Cell Proliferation and Pancreatic-Duodenum Homeobox-1 Expression and Increases Endocrine Cell Mass in the Pancreas of Old, Glucose-Intolerant Rats. Endocrinology (2000) 141(12):4600-5. doi: 10.1210/endo.141.12.7806

90. Holz GGIV, Kiihtreiber WM, Habener JF. Pancreatic Beta-Cells Are Rendered Glucose-Competent by the Insulinotropic Hormone Glucagon-
Like Peptide-1 (7-37). Nature (1993) 361(6410):362-5. doi: 10.1038/ $361362 \mathrm{a} 0$

91. Lee A, Patrick P, Wishart J, Horowitz M, Morley J. The Effects of Miglitol on Glucagon-Like Peptide-1 Secretion and Appetite Sensations in Obese Type 2 Diabetics. Diabetes Obes Metab (2002) 4(5):329-35. doi: 10.1046/j.14631326.2002.00219.x

92. Takei I, Miyamoto K, Funae O, Ohashi N, Meguro S, Tokui M, et al. Secretion of GIP in Responders to Acarbose in Obese Type 2 (NIDDM) Patients. J Diabetes Complications (2001) 15(5):245-9. doi: 10.1016/S10568727(01)00148-9

93. Halimi S, Le Berre M, Grange V. Efficacy and Safety of Acarbose Add-on Therapy in the Treatment of Overweight Patients With Type 2 Diabetes Inadequately Controlled With Metformin: A Double-Blind, PlaceboControlled Study. Diabetes Res Clin Pract (2000) 50(1):49-56. doi: 10.1016/S0168-8227(00)00163-7

94. Phillips P, Karrasch J, Scott R, Wilson D, Moses R. Acarbose Improves Glycemic Control in Overweight Type 2 Diabetic Patients Insufficiently Treated With Metformin. Diabetes Care (2003) 26(2):269-73. doi: 10.2337/ diacare.26.2.269

95. Chaitman B, Hardison RM, Adler D, Gebhart S, Grogan M, Ocampo S, et al. Bypass Angioplasty Revascularization Investigation 2 Diabetes (BARI 2d) Study Group. The Bypass Angioplasty Revascularization Investigation 2 Diabetes Randomized Trial of Different Treatment Strategies in Type 2 Diabetes Mellitus With Stable Ischemic Heart Disease: Impact of Treatment Strategy on Cardiac Mortality and Myocardial Infarction. Circulation (2009) 120(25):2529-40. doi: 10.1161/CIRCULATIONAHA.109.913111

96. Marcinkiewicz A, Ostrowski S, Drzewoski J. Can the Onset of Heart Failure be Delayed by Treating Diabetic Cardiomyopathy? Diabetol Metab Syndrome (2017) 9(1):21. doi: 10.1186/s13098-017-0219-z

97. Asirvatham AR, Mahadevan S, Kumar BS, Nrusimha SD, Vadivel TR, et al. Insulin (Technique) Induced Hypoglycaemia. J Clin Diagn Res: JCDR (2017) 11(5):OD12. doi: 10.7860/JCDR/2017/26203.9809

98. Su T, Xiao Y, Xiao Y, Guo Q, Li C, Huang Y, et al. Bone Marrow Mesenchymal Stem Cells-Derived Exosomal MiR-29b-3p Regulates AgingAssociated Insulin Resistance. ACS Nano (2019) 13(2):2450-62. doi: 10.1021/acsnano.8b09375

99. Sangalli E, Tagliabue E, Sala LL, Prattichizzo F, Uccellatore A, Spada D, et al. Circulating microRNA-15a Associates With Retinal Damage in Patients With Early Stage Type 2 Diabetes. Front Endocrinol (Lausanne) (2020) 11:254. doi: $10.3389 /$ fendo.2020.00254

100. Duh EJ, Sun JK, Stitt AW. Diabetic Retinopathy: Current Understanding, Mechanisms, and Treatment Strategies. JCI Insight (2017) 2(14):e93751. doi: 10.1172/jci.insight.93751

101. Xue R, Gui D, Zheng L, Zhai R, Wang F, Wang N. Mechanistic Insight and Management of Diabetic Nephropathy: Recent Progress and Future Perspective. J Diabetes Res (2017) 2017:7. doi: 10.1155/2017/1839809

102. Von Mering J, Minkowski O. Diabetes Mellitus After Pancreas Extirpation. Arch Exp Pathol Pharmakol (1889) 26:111.

103. Largiadèr F, Kolb E, Binswanger U. A Long-Term Functioning Human Pancreatic Islet Allotransplant. Transplantation (1980) 2976(1):76. doi: 10.1097/00007890-198001000-00017

104. Najarian J, Sutherland DE, Matas AJ, Steffes MW, Simmons RL, Goetz FC. Human Islet Transplantation: A Preliminary Report. Transplant Proc (1977) 9(1):233-6.

105. Kawahara T, Kin T, Kashkoush S, Gala-Lopez B, Bigam DL, Kneteman NM, et al. Portal Vein Thrombosis Is a Potentially Preventable Complication in Clinical Islet Transplantation. Am J Transplant (2011) 11(12):2700-7. doi: 10.1111/j.1600-6143.2011.03717.x

106. Villiger P, Ryan E, Owen R, O'Kelly K, Oberholzer J, Saif FA, et al. Prevention of Bleeding After Islet Transplantation: Lessons Learned From a Multivariate Analysis of 132 Cases at a Single Institution. Am J Transplant (2005) 5 (12):2992-8. doi: 10.1111/j.1600-6143.2005.01108.x

107. Ryan EA, Paty BW, Senior PA, Bigam D, Alfadhli E, Kneteman NM, et al. Five-Year Follow-Up After Clinical Islet Transplantation. Diabetes (2005) 54 (7):2060-9. doi: 10.2337/diabetes.54.7.2060

108. Bosi E, Braghi S, Maffi P, Scirpoli M, Bertuzzi F, Pozza G, et al. Autoantibody Response to Islet Transplantation in Type 1 Diabetes. Diabetes (2001) 50 (11):2464-71. doi: 10.2337/diabetes.50.11.2464 
109. Al-Adra DP, Gill RS, Imes S, O'Gorman D, Kin T, Axford SJ, et al. SingleDonor Islet Transplantation and Long-Term Insulin Independence in Select Patients With Type 1 Diabetes Mellitus. Transplantation (2014) 98(9):100712. doi: $10.1097 / \mathrm{TP} .0000000000000217$

110. Sui L, Danzl N, Campbell SR, Viola R, Williams D, Xing Y, et al. $\beta$-Cell Replacement in Mice Using Human Type 1 Diabetes Nuclear Transfer Embryonic Stem Cells. Diabetes (2018) 67(1):26-35. doi: 10.2337/db17-0120

111. Loh K, Shi Y-C, Walters S, Bensellam M, Lee K, Dezaki K, et al. Inhibition of Y1 Receptor Signaling Improves Islet Transplant Outcome. Nat Commun (2017) 8(1):1-12. doi: 10.1038/s41467-017-00624-2

112. Shi H, Xu X, Zhang B, Xu J, Pan Z, Gong A, et al. 3, 3'-Diindolylmethane Stimulates Exosomal Wnt11 Autocrine Signaling in Human Umbilical Cord Mesenchymal Stem Cells to Enhance Wound Healing. Theranostics (2017) 7 (6):1674. doi: 10.7150/thno.18082

113. Linard C, Brachet M, L'homme B, Strup-Perrot C, Busson E, Bonneau M, et al. Long-Term Effectiveness of Local BM-MSCs for Skeletal Muscle Regeneration: A Proof of Concept Obtained on a Pig Model of Severe Radiation Burn. Stem Cell Res Ther (2018) 9(1):299. doi: 10.1186/s13287018-1051-6

114. Si Y, Zhao Y, Hao H, Liu J, Guo Y, Mu Y, et al. Infusion of Mesenchymal Stem Cells Ameliorates Hyperglycemia in Type 2 Diabetic Rats: Identification of a Novel Role in Improving Insulin Sensitivity. Diabetes (2012) 61(6):1616-25. doi: 10.2337/db11-1141

115. Hao H, Liu J, Shen J, Zhao Y, Liu H, Hou Q, et al. Multiple Intravenous Infusions of Bone Marrow Mesenchymal Stem Cells Reverse Hyperglycemia in Experimental Type 2 Diabetes Rats. Biochem Biophys Res Commun (2013) 436(3):418-23. doi: 10.1016/j.bbrc.2013.05.117

116. Xv J, Ming Q, Wang X, Zhang W, Li Z, Wang S, et al. Mesenchymal Stem Cells Moderate Immune Response of Type 1 Diabetes. Cell Tissue Res (2017) 368(2):239-48. doi: 10.1007/s00441-016-2499-2

117. Guan LX, Guan H, Li HB, Ren CA, Liu L, Chu JJ, et al. Therapeutic Efficacy of Umbilical Cord-Derived Mesenchymal Stem Cells in Patients With Type 2 Diabetes. Exp Ther Med (2015) 9(5):1623-30. doi: 10.3892/etm.2015.2339

118. Rackham CL, Vargas AE, Hawkes RG, Amisten S, Persaud SJ, Austin AL, et al. Annexin A1 Is a Key Modulator of Mesenchymal Stromal CellMediated Improvements in Islet Function. Diabetes (2016) 65(1):129-39. doi: $10.2337 / \mathrm{db} 15-0990$

119. Kerby A, Jones ES, Jones PM, King AJ. Co-Transplantation of Islets With Mesenchymal Stem Cells in Microcapsules Demonstrates Graft Outcome can be Improved in an Isolated-Graft Model of Islet Transplantation in Mice. Cytotherapy (2013) 15(2):192-200. doi: 10.1016/j.jcyt.2012.10.018

120. Li H-T, Jiang F-X, Shi P, Zhang T, Liu X-Y, Lin X-W, et al. In Vitro Reprogramming of Rat bmMSCs Into Pancreatic Endocrine-Like Cells. In Vitro. Cell Dev Biology Animal (2017) 53(2):157-66. doi: 10.1007/s11626016-0087-0

121. Van Pham P, Nguyen PT-M, Nguyen AT-Q, Pham VM, Bui AN-T, Dang LT-T, et al. Improved Differentiation of Umbilical Cord Blood-Derived Mesenchymal Stem Cells Into Insulin-Producing Cells by PDX-1 mRNA Transfection. Differentiation (2014) 87(5):200-8. doi: 10.1016/ j.diff.2014.08.001

122. O’Loughlin A, Kulkarni M, Creane M, Vaughan EE, Mooney E, Shaw G, et al. Topical Administration of Allogeneic Mesenchymal Stromal Cells Seeded in a Collagen Scaffold Augments Wound Healing and Increases Angiogenesis in the Diabetic Rabbit Ulcer. Diabetes (2013) 62(7):2588-94. doi: $10.2337 / \mathrm{db} 12-1822$

123. Wang H, Chen L, Liu Y, Luo B, Xie N, Tan T, et al. Implantation of PlacentaDerived Mesenchymal Stem Cells Accelerates Murine Dermal Wound Closure Through Immunomodulation. Am J Trans Res (2016) 8(11):4912.

124. Fang Y, Tian X, Bai S, Fan J, Hou W, Tong H, et al. Autologous Transplantation of Adipose-Derived Mesenchymal Stem Cells Ameliorates Streptozotocin-Induced Diabetic Nephropathy in Rats by Inhibiting Oxidative Stress, Pro-Inflammatory Cytokines and the P38 MAPK Signaling Pathway. Int J Mol Med (2012) 30(1):85-92. doi: 10.3892/ijmm.2012.977

125. Lv S-S, Liu G, Wang J-P, Wang W-W, Cheng J, Sun A-L, et al. Mesenchymal Stem Cells Transplantation Ameliorates Glomerular Injury in Streptozotocin-Induced Diabetic Nephropathy in Rats via Inhibiting Macrophage Infiltration. Int Immunopharmacol (2013) 17(2):275-82. doi: 10.1016/j.intimp.2013.05.031
126. Lv S, Cheng J, Sun A, Li J, Wang W, Guan G, et al. Mesenchymal Stem Cells Transplantation Ameliorates Glomerular Injury in Streptozotocin-Induced Diabetic Nephropathy in Rats via Inhibiting Oxidative Stress. Diabetes Res Clin Pract (2014) 104(1):143-54. doi: 10.1016/j.diabres.2014.01.011

127. Sun C-K, Yen C-H, Lin Y-C, Tsai T-H, Chang L-T, Kao Y-H, et al. Autologous Transplantation of Adipose-Derived Mesenchymal Stem Cells Markedly Reduced Acute Ischemia-Reperfusion Lung Injury in a Rodent Model. J Trans Med (2011) 9(1):1-13. doi: 10.1186/1479-5876-9-118

128. Han JW, Choi D, Lee MY, Huh YH, Yoon Y-s. Bone Marrow-Derived Mesenchymal Stem Cells Improve Diabetic Neuropathy by Direct Modulation of Both Angiogenesis and Myelination in Peripheral Nerves. Cell Transplant (2016) 25(2):313-26. doi: 10.3727/096368915X688209

129. Aziz MTA, El-Asmar MF, Haidara M, Atta HM, Roshdy NK, Rashed LA, et al. Effect of Bone Marrow-Derived Mesenchymal Stem Cells on Cardiovascular Complications in Diabetic Rats. Med Sci Monit (2008) 14 (11):BR249-55. doi: 10.12659/MSM.935005

130. Zhang W, Wang Y, Kong J, Dong M, Duan H, Chen S. Therapeutic Efficacy of Neural Stem Cells Originating From Umbilical Cord-Derived Mesenchymal Stem Cells in Diabetic Retinopathy. Sci Rep (2017) 7(1):1-8. doi: 10.1038/s41598-017-00298-2

131. Wang W-T, Chen Y-Q. Circulating miRNAs in Cancer: From Detection to Therapy. J Hematol Oncol (2014) 7(1):86. doi: 10.1186/s13045-014-0086-0

132. Zhu W, Xu W, Jiang R, Qian H, Chen M, Hu J, et al. Mesenchymal Stem Cells Derived From Bone Marrow Favor Tumor Cell Growth In Vivo. Exp Mol Pathol (2006) 80(3):267-74. doi: 10.1016/j.yexmp.2005.07.004

133. Tatum JA, Meneveau MO, Brayman KL. Single-Donor Islet Transplantation in Type 1 Diabetes: Patient Selection and Special Considerations. Diabetes Metab Syndrome Obes: Targets Ther (2017) 10:73. doi: 10.2147/ DMSO.S105692

134. Prantl L, Muehlberg F, Navone NM, Song YH, Vykoukal J, Logothetis CJ, et al. Adipose Tissue-Derived Stem Cells Promote Prostate Tumor Growth. Prostate (2010) 70(15):1709-15. doi: 10.1002/pros.21206

135. Shinagawa K, Kitadai $Y$, Tanaka M, Sumida T, Kodama M, Higashi Y, et al. Mesenchymal Stem Cells Enhance Growth and Metastasis of Colon Cancer. Int J Cancer (2010) 127(10):2323-33. doi: 10.1002/ijc.25440

136. Yu JM, Jun ES, Bae YC, Jung JS. Mesenchymal Stem Cells Derived From Human Adipose Tissues Favor Tumor Cell Growth In Vivo. Stem Cells Dev (2008) 17(3):463-74. doi: 10.1089/scd.2007.0181

137. Moll G, Rasmusson-Duprez I, von Bahr L, Connolly-Andersen AM, Elgue G, Funke L, et al. Are Therapeutic Human Mesenchymal Stromal Cells Compatible With Human Blood? Stem Cells (2012) 30(7):1565-74. doi: $10.1002 /$ stem.1111

138. Tatsumi K, Ohashi K, Matsubara Y, Kohori A, Ohno T, Kakidachi H, et al. Tissue Factor Triggers Procoagulation in Transplanted Mesenchymal Stem Cells Leading to Thromboembolism. Biochem Biophys Res Commun (2013) 431(2):203-9. doi: 10.1016/j.bbrc.2012.12.134

139. Xiao Y, Jiang Z-J, Pang Y, Li L, Gao Y, Xiao H-W, et al. Efficacy and Safety of Mesenchymal Stromal Cell Treatment From Related Donors for Patients With Refractory Aplastic Anemia. Cytotherapy (2013) 15(7):760-6. doi: 10.1016/j.jcyt.2013.03.007

140. Ankrum J, Karp JM. Mesenchymal Stem Cell Therapy: Two Steps Forward, One Step Back. Trends Mol Med (2010) 16(5):203-9. doi: 10.1016/ j.molmed.2010.02.005

141. Yang L, Bin Z, Hui S, Rong L, You B, Wu P, et al. The Role of CDRlas in Proliferation and Differentiation of Human Umbilical Cord-Derived Mesenchymal Stem Cells. Stem Cells Int (2019) 2019. doi: 10.1155/2019/ 2316834

142. Ye Z, Lu W, Liang L, Tang M, Wang Y, Li Z, et al. Mesenchymal Stem Cells Overexpressing Hepatocyte Nuclear Factor-4 Alpha Alleviate Liver Injury by Modulating Anti-Inflammatory Functions in Mice. Stem Cell Res Ther (2019) 10(1):1-10. doi: 10.1186/s13287-019-1260-7

143. Ambery AG, Tackett L, Penque BA, Brozinick JT, Elmendorf JS. Exercise Training Prevents Skeletal Muscle Plasma Membrane Cholesterol Accumulation, Cortical Actin Filament Loss, and Insulin Resistance in C57 BL/6J Mice Fed a Western-Style High-Fat Diet. Physiol Rep (2017) 5 (16):e13363. doi: 10.14814/phy2.13363

144. Narendran P, Jackson N, Daley A, Thompson D, Stokes K, Greenfield S, et al. Exercise to Preserve $\beta$-Cell Function in Recent-Onset Type 1 Diabetes 
Mellitus (EXTOD)-A Randomized Controlled Pilot Trial. Diabetic Med (2017) 34(11):1521-31. doi: 10.1111/dme.13439

145. Frühbeis C, Helmig S, Tug S, Simon P, Krämer-Albers E-M. Physical Exercise Induces Rapid Release of Small Extracellular Vesicles Into the Circulation. J Extracellular Vesicles (2015) 4(1):28239. doi: 10.3402/ jev.v4.28239

146. Safdar A, Tarnopolsky MA. Exosomes as Mediators of the Systemic Adaptations to Endurance Exercise. Cold Spring Harbor Perspect Med (2018) 8(3):a029827. doi: 10.1101/cshperspect.a029827

147. Garcia NA, Moncayo-Arlandi J, Sepulveda P, Diez-Juan A. Cardiomyocyte Exosomes Regulate Glycolytic Flux in Endothelium by Direct Transfer of GLUT Transporters and Glycolytic Enzymes. Cardiovasc Res (2016) 109 (3):397-408. doi: 10.1093/cvr/cvv260

148. Chaturvedi P, Kalani A, Medina I, Familtseva A, Tyagi SC. Cardiosome Mediated Regulation of MMP 9 in Diabetic Heart: Role of Mir29b and Mir455 in Exercise. J Cell Mol Med (2015) 19(9):2153-61. doi: 10.1111/ jcmm. 12589

149. Sun Y, Shi H, Yin S, Ji C, Zhang X, Zhang B, et al. Human Mesenchymal Stem Cell Derived Exosomes Alleviate Type 2 Diabetes Mellitus by Reversing Peripheral Insulin Resistance and Relieving $\beta$-Cell Destruction. ACS Nano (2018) 12(8):7613-28. doi: 10.1021/acsnano.7b07643

150. Zhu Q, Zhu R, Jin J. Neutral Ceramidase-Enriched Exosomes Prevent Palmitic Acid-Induced Insulin Resistance in H4 IIEC 3 Hepatocytes. FEBS Open Bio (2016) 6(11):1078-84. doi: 10.1002/2211-5463.12125

151. Davidson SM, Riquelme JA, Takov K, Vicencio JM, Boi-Doku C, Khoo V, et al. Cardioprotection Mediated by Exosomes Is Impaired in the Setting of Type II Diabetes But Can Be Rescued by the Use of Non-Diabetic Exosomes In Vitro. J Cell Mol Med (2018) 22(1):141-51. doi: 10.1111/jcmm.13302

152. Li X, Jiang C, Zhao J. Human Endothelial Progenitor Cells-Derived Exosomes Accelerate Cutaneous Wound Healing in Diabetic Rats by Promoting Endothelial Function. J Diabetes Complications (2016) 30 (6):986-92. doi: 10.1016/j.jdiacomp.2016.05.009

153. Zhang J, Chen C, Hu B, Niu X, Liu X, Zhang G, et al. Exosomes Derived From Human Endothelial Progenitor Cells Accelerate Cutaneous Wound Healing by Promoting Angiogenesis Through Erk1/2 Signaling. Int J Biol Sci (2016) 12(12):1472. doi: 10.7150/ijbs.15514

154. Yen S, Tsai C, Vela P. Gestational Diabetogenesis: Quantitative Analyses of Glucose-Insulin Interrelationship Between Normal Pregnancy and Pregnancy With Gestational Diabetes. Am J Obstet Gynecol (1971) 111 (6):792-800. doi: 10.1016/0002-9378(71)90490-X

155. McIntyre HD, Catalano P, Zhang C, Desoye G, Mathiesen ER, Damm P. Gestational Diabetes Mellitus. Diabetes Care (2019) 5(1):1-19. doi: 10.1038/ s41572-019-0098-8

156. Saravanan P, Magee LA, Banerjee A, Coleman MA, Von Dadelszen P, Denison F, et al. Gestational Diabetes: Opportunities for Improving Maternal and Child Health. Lancet Diabetes Endocrinol (2020) 8(9):793800. doi: $10.1016 / \mathrm{S} 2213-8587(20) 30161-3$

157. American Diabetes Association.Gynecol, C.o.P.B.O.J.O., ACOG Practice Bulletin No. 190: Gestational Diabetes Mellitus. Obstet Gynecol (2018) 131 (2):e49-64.

158. Koivusalo SB, Rönö K, Klemetti MM, Roine RP, Lindström J, Erkkola M, et al. Gestational Diabetes Mellitus can be Prevented by Lifestyle Intervention: The Finnish Gestational Diabetes Prevention Study (RADIEL): A Randomized Controlled Trial. Diabetes Care (2016) 39(1):24-30. doi: 10.2337/dc15-0511

159. Wang C, Wei Y, Zhang X, Zhang Y, Xu Q, Sun Y, et al. A Randomized Clinical Trial of Exercise During Pregnancy to Prevent Gestational Diabetes Mellitus and Improve Pregnancy Outcome in Overweight and Obese Pregnant Women. Am J Obstet Gynecol (2017) 216(4):340-51. doi: 10.1016/j.ajog.2017.01.037

160. Salomon C, Guanzon D, Scholz-Romero K, Longo S, Correa P, Illanes SE, et al. Placental Exosomes as Early Biomarker of Preeclampsia: Potential Role of Exosomal microRNAs Across Gestation. J Clin Endocrinol Metab (2017) 102(9):3182-94. doi: 10.1210/jc.2017-00672

161. Magayr TA, Song X, Streets AJ, Vergoz L, Chang L, Valluru MK, et al. Global microRNA Profiling in Human Urinary Exosomes Reveals Novel Disease Biomarkers and Cellular Pathways for Autosomal Dominant Polycystic Kidney Disease. Kidney Int (2020) 98(2):420-35. doi: 10.1016/j.kint. 2020.02.008
162. Pegtel DM, Gould SJ. Exosomes (2019) 88:487-514. doi: 10.1146/annurevbiochem-013118-111902

163. Mathieu M, et al. Specificities of Secretion and Uptake of Exosomes and Other Extracellular Vesicles for Cell-to-Cell Communication. Nat Cell Biol (2019) 21(1):9-17. doi: 10.1038/s41556-018-0250-9

164. Salomon C, Scholz-Romero K, Sarker S, Sweeney E, Kobayashi M, Correa P, et al. Gestational Diabetes Mellitus Is Associated With Changes in the Concentration and Bioactivity of Placenta-Derived Exosomes in Maternal Circulation Across Gestation. Diabetes (2016) 65(3):598-609. doi: 10.2337/ db15-0966

165. Saez T, De Vos P, Sobrevia L, Faas MM. Is There a Role for Exosomes in Foetoplacental Endothelial Dysfunction in Gestational Diabetes Mellitus? Placenta (2018) 61:48-54. doi: 10.1016/j.placenta.2017.11.007

166. Sáez Gutiérrez TA. Role of Fetoplacental Exosomes in Fetoplacental Endothelial Dysfunction in Gestational Diabetes Mellitus. University of Groningen. (2017).

167. Cilvik SN, Wesolowski SR, Anthony RV, Brown LD, Rozance PJ. Late Gestation Fetal Hyperglucagonaemia Impairs Placental Function and Results in Diminished Fetal Protein Accretion and Decreased Fetal Growth. J Physiol (2021) 599(13):3403-27. doi: 10.1113/JP281288

168. Olmos-Ortiz A, Flores-Espinosa P, Díaz L, Velázquez P, Ramírez-Isarraraz C, Zaga-Clavellina V. Immunoendocrine Dysregulation During Gestational Diabetes Mellitus: The Central Role of the Placenta. Int J Mol Sci (2021) 22 (15):8087. doi: 10.3390/ijms22158087

169. Aswad H, Forterre A, Wiklander OP, Vial G, Danty-Berger E, Jalabert A, et al. Exosomes Participate in the Alteration of Muscle Homeostasis During Lipid-Induced Insulin Resistance in Mice. Diabetologia (2014) 57(10):215564. doi: 10.1007/s00125-014-3337-2

170. Deng Z-B, Poliakov A, Hardy RW, Clements R, Liu C, Liu Y, et al. Adipose Tissue Exosome-Like Vesicles Mediate Activation of Macrophage-Induced Insulin Resistance. Diabetes (2009) 58(11):2498-505. doi: 10.2337/db090216

171. Togel F, Weiss K, Yang Y, Hu Z, Zhang P, Westenfelder C. Vasculotropic, Paracrine Actions of Infused Mesenchymal Stem Cells Are Important to the Recovery From Acute Kidney Injury. Am J Physiol Renal Physiol (2007) 292 (5):F1626-35. doi: 10.1152/ajprenal.00339.2006

172. Camussi G, Deregibus MC, Tetta C. Paracrine/endocrine Mechanism of Stem Cells on Kidney Repair: Role of Microvesicle-Mediated Transfer of Genetic Information. Curr Opin Nephrol Hypertension (2010) 19(1):7-12. doi: 10.1097/MNH.0b013e328332fb6f

173. Park JH, Hwang I, Hwang SH, Han H, Ha H. Human Umbilical Cord BloodDerived Mesenchymal Stem Cells Prevent Diabetic Renal Injury Through Paracrine Action. Diabetes Res Clin Pract (2012) 98(3):465-73. doi: 10.1016/ j.diabres.2012.09.034

174. Zhang S, Chuah SJ, Lai RC, Hui JHP, Lim SK, Toh WS. MSC Exosomes Mediate Cartilage Repair by Enhancing Proliferation, Attenuating Apoptosis and Modulating Immune Reactivity. Biomaterials (2018) 156:16-27. doi: 10.1016/j.biomaterials.2017.11.028

175. Bu N, Wu H-Q, Zhang G-L, Zhan S-Q, Zhang R, Fan Q-Y, et al. Immature Dendritic Cell Exosomes Suppress Experimental Autoimmune Myasthenia Gravis. J Neuroimmunol (2015) 285:71-5. doi: 10.1016/j.jneuroim.2015. 04.009

176. Xue C, Shen Y, Li X, Li B, Zhao S, Gu J, et al. Exosomes Derived From Hypoxia-Treated Human Adipose Mesenchymal Stem Cells Enhance Angiogenesis Through the PKA Signaling Pathway. Stem Cells Dev (2018) 27(7):456-65. doi: 10.1089/scd.2017.0296

177. Wen D, Peng Y, Liu D, Weizmann Y, Mahato RI. Mesenchymal Stem Cell and Derived Exosome as Small RNA Carrier and Immunomodulator to Improve Islet Transplantation. J Controlled Release (2016) 238:166-75. doi: 10.1016/ j.jconrel.2016.07.044

178. Shabbir A, Cox A, Rodriguez-Menocal L, Salgado M, Badiavas EV. Mesenchymal Stem Cell Exosomes Induce Proliferation and Migration of Normal and Chronic Wound Fibroblasts, and Enhance Angiogenesis In Vitro. Stem Cells Dev (2015) 24(14):1635-47. doi: 10.1089/scd.2014.0316

179. Nakano M, Nagaishi K, Konari N, Saito Y, Chikenji T, Mizue Y, et al. Bone Marrow-Derived Mesenchymal Stem Cells Improve Diabetes-Induced Cognitive Impairment by Exosome Transfer Into Damaged Neurons and Astrocytes. Sci Rep (2016) 6:24805. doi: 10.1038/srep24805 
180. Nagaishi K, Mizue Y, Chikenji T, Otani M, Nakano M, Saijo Y, et al. Umbilical Cord Extracts Improve Diabetic Abnormalities in Bone MarrowDerived Mesenchymal Stem Cells and Increase Their Therapeutic Effects on Diabetic Nephropathy. Sci Rep (2017) 7(1):1-17. doi: 10.1038/s41598-01708921-y

181. Li H, Liu D, Li C, Zhou S, Tian D, Xiao D, et al. Exosomes Secreted From Mutant-HIF-1 $\alpha$-Modified Bone-Marrow-Derived Mesenchymal Stem Cells Attenuate Early Steroid-Induced Avascular Necrosis of Femoral Head in Rabbit. Cell Biol Int (2017) 41(12):1379-90. doi: 10.1002/cbin.10869

182. Jabbari N, Akbariazar E, Feqhhi M, Rahbarghazi R, Rezaie J. Breast CancerDerived Exosomes: Tumor Progression and Therapeutic Agents. J Cell Physiol (2020) 235(10):6345-56. doi: 10.1002/jcp.29668

183. Guo Y, Chen Y, Han P, Liu Y, Li W, Zhu F, et al. Biocompatible ChitosanCarbon Nanocage Hybrids for Sustained Drug Release and Highly Efficient Laser and Microwave Co-Irradiation Induced Cancer Therapy. Acta Biomater (2020) 103:237-46. doi: 10.1016/j.actbio.2019.12.010

184. Jiang L, Dong H, Cao H, Ji X, Luan S, Liu J. Exosomes in Pathogenesis, Diagnosis, and Treatment of Alzheimer's Disease. Med Sci Monit (2019) 25:3329. doi: 10.12659/MSM.914027

185. Rosenberger L, Ezquer M, Lillo-Vera F, Pedraza PL, Ortúzar MI, González PL, et al. Stem Cell Exosomes Inhibit Angiogenesis and Tumor Growth of Oral Squamous Cell Carcinoma. Sci Rep (2019) 9(1):1-12. doi: 10.1038/ s41598-018-36855-6

186. Bian X, Ma K, Zhang C, Fu X. Therapeutic Angiogenesis Using Stem CellDerived Extracellular Vesicles: An Emerging Approach for Treatment of Ischemic Diseases. Stem Cell Res Ther (2019) 10(1):1-18. doi: 10.1186/ s13287-019-1276-Z

187. Arslan F, Lai RC, Smeets MB, Akeroyd L, Choo A, Aguor EN, et al. Mesenchymal Stem Cell-Derived Exosomes Increase ATP Levels, Decrease Oxidative Stress and Activate PI3K/Akt Pathway to Enhance Myocardial Viability and Prevent Adverse Remodeling After Myocardial Ischemia/ Reperfusion Injury. Stem Cell Res (2013) 10(3):301-12. doi: 10.1016/ j.scr.2013.01.002

188. Xia C, Zeng Z, Fang B, Tao M, Gu C, Zheng L, et al. Mesenchymal Stem CellDerived Exosomes Ameliorate Intervertebral Disc Degeneration via AntiOxidant and Anti-Inflammatory Effects. Free Radic Biol Med (2019) 143:115. doi: 10.1016/j.freeradbiomed.2019.07.026

189. Karamichali E, Chihab H, Kakkanas A, Marchio A, Karamitros T, Pogka V, et al. HCV Defective Genomes Promote Persistent Infection by Modulating the Viral Life Cycle. Front Microbiol (2018) 9:2942. doi: 10.3389/ fmicb.2018.02942

190. Yang H, Ma Q, Wang Y, Tang Z. Clinical Application of Exosomes and Circulating microRNAs in the Diagnosis of Pregnancy Complications and Foetal Abnormalities. J Transl Med (2020) 18(1):1-9. doi: 10.1186/s12967-02002227-w

191. Ma Z-J, Yang J-J, Lu Y-B, Liu Z-Y, Wang X-X. Mesenchymal Stem Cell-Derived Exosomes: Toward Cell-Free Therapeutic Strategies in Regenerative Medicine. World J Stem Cells (2020) 12(8):814. doi: 10.4252/ wjsc.v12.i8.814

192. Duan Y, Luo Q, Wang Y, Ma Y, Chen F, Zhu X, et al. Adipose Mesenchymal Stem Cell-Derived Extracellular Vesicles Containing microRNA-26a-5p
Target TLR4 and Protect Against Diabetic Nephropathy. J Biol Chem (2020) 295(37):12868-84. doi: 10.1074/jbc.RA120.012522

193. Aurelian SM, Cheta DM, Onicescu D. Microvesicles-Potential Biomarkers for the Interrelations Atherosclerosis/Type 2 Diabetes Mellitus. Rom J Morphol Embryol (2014) 55(3 Suppl):1035-9.

194. Zhang K, Zhao X, Chen X, Wei Y, Du W, Wang Y, et al. Enhanced Therapeutic Effects of Mesenchymal Stem Cell-Derived Exosomes With an Injectable Hydrogel for Hindlimb Ischemia Treatment. ACS Appl Mater Interf (2018) 10(36):30081-91. doi: 10.1021/acsami.8b08449

195. Cheng N-C, Lin W-J, Ling T-Y, Young T-H. Sustained Release of AdiposeDerived Stem Cells by Thermosensitive Chitosan/Gelatin Hydrogel for Therapeutic Angiogenesis. Acta Biomater (2017) 51:258-67. doi: 10.1016/ j.actbio.2017.01.060

196. Shi Q, Qian Z, Liu D, Sun J, Wang X, Liu H, et al. GMSC-Derived Exosomes Combined With a Chitosan/Silk Hydrogel Sponge Accelerates Wound Healing in a Diabetic Rat Skin Defect Model. Front Physiol (2017) 8:904. doi: 10.3389/fphys.2017.00904

197. Shafei S, Khanmohammadi M, Heidari R, Ghanbari H, Taghdiri Nooshabadi V, Farzamfar S, et al. Exosome Loaded Alginate Hydrogel Promotes Tissue Regeneration in Full-Thickness Skin Wounds: An In Vivo Study. J BioMed Mater Res (2020) 108(3):545-56. doi: 10.1002/jbm.a.36835

198. Chen P, Zheng L, Wang Y, Tao M, Xie Z, Xia C, et al. DesktopStereolithography 3D Printing of a Radially Oriented Extracellular Matrix/ Mesenchymal Stem Cell Exosome Bioink for Osteochondral Defect Regeneration. Theranostics (2019) 9(9):2439. doi: 10.7150/thno.31017

199. Peterka O, Jirásko R, Chocholoušková M, Kuchař L, Wolrab D, Hájek R, et al. Lipidomic Characterization of Exosomes Isolated From Human Plasma Using Various Mass Spectrometry Techniques. Biochim Et Biophys Acta Molecular Cell Biol Lipids (2020) 1865(5):158634. doi: 10.1016/ j.bbalip.2020.158634

200. Liao J, Liu R, Yin L, Pu Y. Expression Profiling of Exosomal miRNAs Derived From Human Esophageal Cancer Cells by Solexa High-Throughput Sequencing. Int J Mol Sci (2014) 15(9):15530-51. doi: 10.3390/ ijms 150915530

Conflict of Interest: The authors declare that the research was conducted in the absence of any commercial or financial relationships that could be construed as a potential conflict of interest.

Publisher's Note: All claims expressed in this article are solely those of the authors and do not necessarily represent those of their affiliated organizations, or those of the publisher, the editors and the reviewers. Any product that may be evaluated in this article, or claim that may be made by its manufacturer, is not guaranteed or endorsed by the publisher.

Copyright (c) 2021 Sun, Tao, Wu, Zhang, Liu and Wang. This is an open-access article distributed under the terms of the Creative Commons Attribution License (CC BY). The use, distribution or reproduction in other forums is permitted, provided the original author(s) and the copyright owner(s) are credited and that the original publication in this journal is cited, in accordance with accepted academic practice. No use, distribution or reproduction is permitted which does not comply with these terms. 